\title{
Should Hunting as a Cultural Heritage Be Protected?
}

\author{
Wojciech Dajczak ${ }^{1,2}$ (1) Dariusz J. Gwiazdowicz ${ }^{3,4}$ (1) \\ Aleksandra Matulewska ${ }^{5,6}$ (D) Wojciech Szafrański ${ }^{1,7}$
}

Published online: 16 September 2020

(c) The Author(s) 2020

\begin{abstract}
The paper focuses on hunting as cultural heritage from the semiotic and legal perspectives. The aim of the paper is to determine whether the UNESCO Convention for the Safeguarding of the Intangible Cultural Heritage of 2003 allows recognizing the transmission and exercise of hunting skills within the Polish Hunting Association as a manifestation of intangible cultural heritage. The main research method applied in this research is the test of legal rationality encompassing five elements: (1) the generic coherence of hunting knowledge and skills in Poland; (2) the lack of conflict with the principles arising from universal human rights instruments; (3) the significance of hunting knowledge and skills for nature protection and conservation; (4) the significance of hunting knowledge and skills for economic balance and internal security; and (5) the hunting knowledge and skills versus the idea of naturerelated cultural identity. The newspaper and political discourse is highly emotional loaded and frequently instead of merits is based on propaganda and half-truths. Nowadays hunting in general is perceived as the so-called blood sport not an element of ecology in the nature disturbed by humans. Therefore, the paper is intended to present the UNESCO Convention and facts about Polish hunting model as an element of sustainable nature and environment conservation and protection as well as a tool of biodiversity preservation.
\end{abstract}

Keywords Hunting · Tangible cultural heritage · Intangible cultural heritage · Knowledge about nature and the universe $\cdot$ Hunting culture $\cdot$ Hunting heritage . Cultural heritage law

Aleksandra Matulewska aleksmat@amu.edu.pl

$\bowtie$ Wojciech Szafrański w.szafr@amu.edu.pl

Extended author information available on the last page of the article 


\section{Introduction}

All manifestations of intangible cultural heritage are one of the basic sources of cultural identity [2]. That is why the relationship and mutual interaction of material and intangible heritage is so important. That relationship should be understood as a dynamic rather than static one. The authors contrast the characteristic of the material heritage of museocentrism or objectocentrism, focusing on the past, with the present and even future vitality of culture and the importance of its depositors, which is the key to understanding the intangible cultural heritage [28: 27-28]; [1]. The process of humanizing the law of cultural heritage, participating in it here and now in a far more complete way is possible in the area of intangible cultural heritage.

In view of the universality of ratification of the UNESCO Convention for the Safeguarding of the Intangible Cultural Heritage (ICH) of 2003 [103], there is no doubt that the intangible cultural heritage is not only an integral part of cultural heritage, but more importantly the element that is on the one hand the most expansive, and on the other hand raises the most questions and doubts. ICH does not play a significant role even in such basic issues as the definition of intangible cultural heritage, because much more important are international and national practices recognizing the manifestations of a given intangible heritage as significant, and thus worth protecting. In addition, a fundamental contradiction is revealed in this practice, because the hitherto universalist approach to the heritage of humanity, which has been shaped in relation to the material cultural heritage, at the same time has involuntarily caused the cultivation of cultural and political rivalry between states and propagating the concepts of "uniqueness" or "exceptional value" which is far different from the assumptions underlying ICH and the shaping of practice in relation to the intangible cultural heritage [4:382]. The practice should be based not on competition but on coexistence, in accordance with the external manifestation of that intention observed at the stage of convention creation when the term universal heritage of humanity was replaced with the term universal will in relation to the protection of intangible cultural heritage [63: 118].

Both these elements of heritage, i.e. tangible and intangible, are simultaneously accompanied by an internal contradiction of the special interest of a given nation, state or group defined in different ways in relation to a specific cultural heritage-which are far more present in relation to the intangible cultural heritage. To a lesser extent, it is a problem of interpreting the convention itself, and adopting the practice of its implementation. This is why the fetish is an element that is by no means the most important in the overall analysis of the protection of intangible cultural heritage, i.e. the lists. The creators of $\mathrm{ICH}$ wanted to avoid the petrification of intangible heritage in the form of all kinds of lists, registers, references at international or national levels, but ultimately the practice shows that those lists are currently the most important determinant of eligibility for being classified as the intangible heritage. What is more, they are not perceived as the identification or inventory of intangible cultural heritage requiring protection 
(which has been the foundation of the convention) but as a kind of state glaze, which from the national level can potentially be transferred to a higher level, i.e. may become the international glaze [61: 352-254].

Writing about the convention as the greatest triumph of the law of protection of cultural heritage in the last 20 years is an exaggeration as we are all yet to learn this convention, work it out, because this convention (like many others) is not only a legal instrument, but also social or simply political one, which may result in converting it into an argument in the socio-political debate on the hierarchy of values depending on immediate needs, and even may directly constitute a field for abuse in this respect [64: 440]. Paradoxically, thus, the specific manifestations of intangible cultural heritage can be compared to Proteus - a sea deity in Greek mythology who had the ability to change his form. The specific manifestations of intangible cultural heritage are Proteuses and remain so, although they take different forms and are presented in different ways by political decision makers, often as a result of the needs of the current narrative, in particular in situations of potential disputes between different social groups. This is the mechanism that Lowenthal [39: 277] illustrates claiming that too much is required of heritage as we simultaneously recommend that we share and protect national, regional, ethnic and global heritages. We forget that these goals are usually incompatible, and that too much is expected of heritage.

At the same time it is the semiotic context which shapes our perception of the world and phenomena present around us. In public debates, a specific example of intangible heritage can be described as something good or bad. Rules of conduct that distinguish a particular group may raise other people's objections. Art. 2 clause 1 of the Convention [103] does not enable to solve that problem in a straightforward manner [68]. According to it, "consideration will be given solely to such intangible cultural heritage as is compatible with existing international human rights instruments, as well as with the requirements of mutual respect among communities, groups and individuals, and of sustainable development." The removal in December 2019 from the Representative List of the Intangible Cultural Heritage of Humanity of the festivals in Aalst shows that when the behaviours covered by it provoke criticism, such a form of cultural heritage, may lose its status as a legally protected domain [84]. The criticism of behaviour at the Aalst festival has not been massive. The problem in question is the admissibility of censorship of tradition. The solution to this conflict which was supposed to be based on such values as dignity, equality and mutual respect essentially favoured political correctness rather than the freedom of satirical symbolism that is fundamental to the festival. The political procedure of recognizing the legal significance of specific manifestations of intangible heritage (and consequential inclusion on the list) may cause that political correctness will become an important brake on such procedures. Of course, recognizing such values as dignity and mutual respect has a broad cultural basis. Their universal nature results from the Universal Declaration of Human Rights of 1948 [106]. However, with regard to behaviours that give rise to limited but strong opposition in public debate, political correctness may expand the limits of their understanding. Such criticized behaviour may be the development, transfer and use of hunting skills. An example of such criticism may be the activity of some activists who negate any interference in the natural environment, including the activity of hunters reducing the 


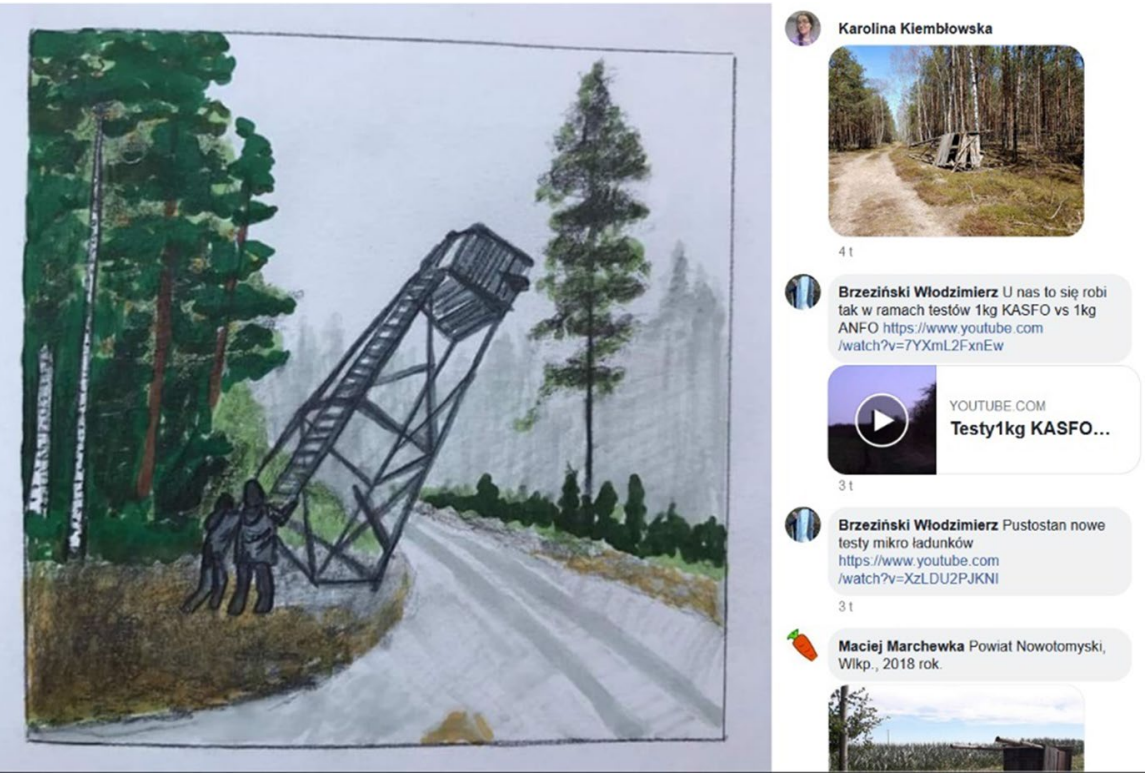

Fig. 1 Instruction how to demolish a hunting stand [95]

excessive numbers of selected animal species. The narrative of such critics is often based on arousing emotions by humanizing animals-giving them human features, depicting in photographs or referring to young animals in the text (baby scheme), which always strengthens the message, as in the following example: "Hunters kill red deer and fallow deer calves, roe deer kids, mouflon lambs, wild boar piglets. They kill children. They may kill the children of wild boars-the piglets from the moment they finish 1 day" [82]. In addition, cyberbullying directed at hunters is developing more and more, and over time it frequently escalates transforming into ecoterrorism [46]. An example would be the organization Poznań Against Hunters promoting the destruction of hunting equipment and facilities (Fig. 1).

The counterweight to the negative stigmatization of the necessary activity of hunters carried out - even in good faith-in the name of political correctness would be to recognize them as deserving protection within the scope of intangible heritage. Prott [56: 386] has generally recognized that hunting is located in all five domains of intangible heritage referred to by ICH. Recognizing the limits of the application of this convention based on human rights, she stated that only individual, national examples of hunting practices, related rituals and reflections on their cultural dimension could be entered into the list [56: 394]. The 2016 decision on Falconry-a living human heritage [85] can be considered an example of an entry into this representative list in accordance with this mode of thinking. It is considered to be a form of intangible heritage manifested in knowledge and practices regarding nature and the universe. Nevertheless, that is how English fox hunting could be assessed but this hunting technique involving dogs was banned by the 2004 Act [93]. With regard to falconry recognized as a heritage protected by the convention, it is emphasized 
that this is increasingly linked to the preservation of the natural environment. However, one can claim that such a hunting technique is based on keeping protected species of birds of prey in captivity [74]. However, the positive assessment of falconry prevails, covering not only the historical and cultural spheres [66] but also the contemporary role consisting, inter alia, in increasing airport security. The work of falconers at airports is to deter birds so that there is no collision with taking off or landing planes, which could pose a threat to the life and health of passengers and crew [97].

It is worth pointing out the specificity of the falconry's entry on the list, which is also one of the most recognizable multinational entries. Having common roots in this area, i.e. similarly as in the case of hunting, falconry is featured by completely different dimensions in individual countries. Furthermore, new countries join this nomination every year (currently 18 countries), and among them there are countries very culturally different, e.g. Belgium, the Czech Republic, Qatar, Mongolia, the South Korea, Syria or the United Arab Emirates. Interestingly, UNESCO uses falconry as an example of international cooperation in the area of good practices, and yet concrete manifestations of the live falconry tradition, and above all the differing and varied cultural and social significance of falconry which are clearly visible in these countries. Thus, one may observe in this case the mechanism of "majority" in political shaping at the international level in relation to manifestations of intangible cultural heritage. The promotion of multinational entries (noticeable in the Operational Directives for the implementation of the Convention for the Safeguarding of the Intangible Heritage of 2014 [96]) allows for easier overcoming doubts of any nature. Finding partners for multinational entries enables to sanction specific manifestations of intangible heritage to a greater extent.

But when we cultivate some culture, can we limit its impact to the level of ethnographic curiosity [16]? Is it not in the interest of the modern and future generations to change the paradigm of looking at hunting as a manifestation of cultural heritage? What happens if we change the perspectives and analyse hunting not as a phenomenon reduced to a special type of hunting and related rituals, possible manifestations of intangible heritage but from a holistic perspective as a conglomerate of skills that are transferred and exercised in a traditionally established manner, and relate to the economic sphere (regulation of animal numbers and damage reduction), nature conservation (reduction of invasive species or reintroduction of endangered species), as well as culture (specific hunting language, literature, music or venisonbased cuisine).

These situations have a common feature because they require a special understanding of the nature in which these actions are undertaken. They constitute interactions with nature. Such an approach seems to be potentially possible on the basis of ICH only if the question is posed whether a particular way of transferring and exercising hunting skills is the heritage manifested in knowledge and practices regarding nature and the world? Such a broad view of hunting as worthy of cultivating, bringing good associations intangible heritage is the subject of attacks in public debates. The freedom of such opinions must be respected. However, the view proposed here creates a space where the recourse to the legal concept of cultural heritage can prevent this debate from being simplified in the name of political correctness. 


\section{Aim and Scope of the Work}

Extensive legal arguments based on ICH should break through the incomplete, blurred arguments of purely political debate. Tradition, legal regulations and modern hunting practice in Poland constitute a good basis for conducting such an extensive test of legal rationality. To clarify the question posed above, we want to determine whether the Convention [103] allows recognizing the transmission and exercise of hunting skills within the Polish Hunting Association (Polski Zwiazek Łowiecki-hereinafter referred to as PZE) as a manifestation of intangible cultural heritage.

\section{Research Methods and Material}

The main research method applied in this research is the test of legal rationality. According to the experience of legal argumentation scholars, the fundamental features of rationality test must be fulfilled simultaneously. Those features encompass the following rules: (1) engaging in argumentation when in doubt; (2) putting forward arguments with conviction of the issue validity and justification; (3) respecting the principle of truthfulness; (4) taking into account factual findings in argumentation; (5) including generally accepted practices and principles in argumentation; (6) conducting argumentation with respect for the principles of freedom and equality, (7) orienting the argumentation directly onto the goal; (8) respecting the basic principles of linguistic communication, and finally (9) taking into account the applicable law and widely accepted legal practices and principles in the course of argumentation [70].

The test proposed and conducted by us includes five elements:

Element 1 the generic coherence of hunting knowledge and skills in Poland;

Element 2 the lack conflict with the principles arising from universal human rights instruments;

Element 3 the significance of hunting knowledge and skills for nature protection and conservation;

Element 4 the significance of hunting knowledge and skills for economic balance and internal security;

Element 5 the hunting knowledge and skills versus the idea of nature-related cultural identity.

Apart from the test scrutinized above, the authors have resorted to the analysis of pertinent literature in the field of intangible cultural heritage, natural sciences, sustainable hunting and hunting and its impact on nature conservation in Poland and abroad.

\section{The Test of Legal Rationality}

Element 1 the generic coherence of hunting knowledge and skills in Poland. 
The formation of the concept of Traditional Knowlegde (TK) as an element of intangible cultural heritage has proceeded through the conceptual extension, i.e. creating a kind of a "larger container" into which, next to already legally and traditionally sanctioned categories of literary, artistic, scholarly or scientific works, as well know-how, another type of knowledge has been inserted that is to say the knowledge of nature and the universe as well as the practices associated with them if transferred from generation to generation. The latter element is constantly being expanded in the course of applying the Convention. Such has been the intention not to create enumerations but to leave a chance to "find" various aspects of knowledge or practices in relation to the world of nature and the universe. In relation to hunting, it is important to prejudge whether there is any coherence of hunting knowledge and skills and to adopt a new approach to the TK in line with Krzysztof Pomian's idea "There is no heritage without heritage awareness" [54: 38].

Analysing hunting as a genus of skills and practices that allow a hunter to kill a game animal requires the authors to ask a question at the beginning of the test for a clear criterion separating these practices from other situations of killing a wild animal. Such boundaries exist. They are created in the Polish legal order by clearly separating the hunts organized within the Polish Hunting Association from the intentional killing of wild animals outside such hunts. The latter instance of illegal killing of an animal constitutes a prohibited act of poaching. Poachers are subject to criminal liability. Article 4.3 of the Hunting Law states "Poaching means the action aimed at taking possession of animals in a way that is not hunting or in violation of the conditions of admissibility of hunting" [80]. Modern poaching has many faces. The best known dimension of poaching is the killing of rare or protected animals such as tigers or elephants to obtain some sort of trophy. But recently we have been observing completely new dimensions of poaching in cities. The environment in continental Europe is urbanized to such an extent that there is no possibility to let the wild animals live without human intervention into the numbers of their populations. It is clearly visible in cities were poaching develops on a large scale. Inhabitants of cities are frequently annoyed by birds which generate noise, spread disease and leave their droppings everywhere. Such persons frequently buy gas guns (for which one does not need a license and which are cheap) and they illegally kill birds which they perceive as nuisance or pests. The mortality rate is hard to assess as that sort of offence is not reported as a rule and the carcasses of birds are cleaned every morning by city cleaners or simply eaten by cats and rats. Sometimes such birds serve as moving targets enabling city inhabitants to practice precision shooting. Pigeons and magpies are often the victims of such exercises of skills in using gas guns on a moving target. The detection rate of such crimes is negligible.

On the other hand, hunting allowed under Polish law is subject to detailed and extremely precise restrictions regarding the species, as well as the manner of hunting, time and place of hunting, gender of hunted species in accordance with the Regulation of the Minister of the Environment of 16 March 2005 on determining hunting periods for game animals [97], the Act of on 13 October 1995 Hunting Law [80] 
and the Regulation of the Minister of the Environment of 22 March 2005 on detailed conditions for hunting and marking carcasses [98]. ${ }^{1}$

For instance Paragraph 12. of the Regulation mentioned above states as follows: "One shall not aim and shoot at animals if:

\footnotetext{
1 Paragraph 3.

1. Only hunting long firearms with rifled or smooth barrels, excluding black-powder firearms, pistols and revolvers are allowed to perform hunting and shooting animals posing extraordinary threat to life, health or human economy, from which, after the maximum load, one can take at most six individual shots, however, only two cartridges can be loaded at a time to the semi-automatic weapon magazine.

2. The hunting weapon used for hunting with rifled barrels must be designed for shooting with hunting ammunition characterized by the energy of a projectile not less than $1000 \mathrm{~J}$ at a distance of $100 \mathrm{~m}$ from the muzzle.
}

3. Subject to paragraph 3.4 hunting for big game may be carried out only with the use of hunting weapons, referred to in paragraph 3.2, and hunting jacketed soft-point cartridges, whereby:

(1) when hunting on elk, the energy of the projectile at a distance of $100 \mathrm{~m}$ from the muzzle may not be less than $2500 \mathrm{~J}$;

(2) when hunting red deer, fallow deer, mouflons and wild boar, excluding boar piglets, the energy of the projectile at a distance of $100 \mathrm{~m}$ from the muzzle may not be less than $2000 \mathrm{~J}$.

4. It is allowed to hunt big game, with the exception of elk and red deer males, using hunting weapons with smooth barrels and hunting shotgun slugs.

5. To perform a hunt for small animals, subject to paragraph 3.6, only hunting weapons with smooth barrels and hunting shots with pellets with a diameter not exceeding $4.5 \mathrm{~mm}$ may be used.

6. Hunting guns with rifled barrels and hunting cartridges with jacketed soft-point and full-metal jackets or hunting weapons with smooth barrels and hunting cartridges listed in paragraph 3.4 and 3.5 shall be used to perform hunting for predators.

Paragraph 6.

1. While hunting, one shall not shoot at:

(1) dominant does;

(2) animals at feeding racks, salt licks, in-forest feeding stop lanes and permanent feeding points, with the exception of wild boars and predators near baiting sites; the hunter shall determine the location of the baiting sites in the hunting district with the lessee or manager of the hunting district, and the lessee or manager of the hunting district shall agree their location in the forest areas with the relevant forest inspectorate;

(3) animals from motor vehicles and their trailers, semi-trailers or other devices attached to them, as well as from horse-drawn vehicles, as well as from power-operated boats with a running engine;

(4) animals on fenced feeding grounds;

(5) birds which are not in flight, with the exception of hazel grouse, geese and Eurasian coots;

(6) hares remaining still;

(7) unrecognized targets.

2. During the hunt, one shall not use:

(1) blinded or mutilated animals as decoys;

(2) devices reproducing the recording of animals' voices for the purpose of attracting and disturbing animals;

(3) electrical or electronic devices that may kill or stun;

(4) mirrors and other blinding devices;

(5) gas and smoke to drive animals out.

Paragraph 7.

1. The hunter may hunt at night at:

(1) muskrats and predators - if the hunter is equipped with a hunting weapon with a mounted optical sight device, mentioned in para. 4.1, and binoculars and a torch;

(1a) wild boars - if the hunter is equipped with a hunting weapon with a mounted optical sight device, mentioned in para. 4.1, and binoculars and a torch;

(2) geese and ducks - on bird gatherings and flights. 
1. there are hunters or other people or farm animals, buildings or vehicles on the firing line, and the distance from them does not guarantee the conditions of firing a safe shot;

2. the game is located on the tops of hills;

3. the game is located less than 200 meters from working farm machines." [98].

The common denominator of these restrictions is the explicit definition of hunting in Polish law as an element of nature protection and conservation in accordance with the principles of ecology and the principles of rational agriculture, forestry and fisheries (Article 1 of hunting law [80]) as well as the preservation of biodiversity and animal welfare in a world disturbed by human development. The acquisition and transfer of knowledge and skills used in legally permitted hunts takes place in a formalized manner. It is specified by the Polish Hunting Association Statute [101], other PZÆ regulations as well as hunting laws [80] and regulations [97, 98] and the soft-law [100]. These and many other legal and soft-law documents, among others, take into account the aging of knowledge. The Supreme Hunting Council Resolution [100] provides that the internship must be completed by candidates who want to obtain: basic, selection and falconry hunting licences. Moreover, within a maximum of 5 years from the date of completion of the internship the candidates should take part in a course which ends with an exam. The condition of admission to the exam for basic, selection and falconry qualifications is participation in a minimum of $60 \%$ of the hours of theoretical classes carried out as part of individual course, with classes in the field described in detail in Sect. 4 (cited in the footnote) section 1 point 1 letter $\mathrm{c}, \mathrm{f}$ and $\mathrm{g}$ must be confirmed by participation in a minimum of $90 \%$ of class hours. $^{2}$

\footnotetext{
2 1. The minimum framework training programs for specific hunting licenses include, in particular:

1) Basic hunting licence to perform hunting:

a) the provisions of the Hunting Act and executive acts $-7 \mathrm{~h}$,

b) Statute of the Polish Hunting Association-2 h,

c) rules and conditions for hunting $-7 \mathrm{~h}$,

d) principles of nature protection, preservation, conservation and protected species-2 $\mathrm{h}$,

e) list of game species, their biology and hunting periods for individual species- $12 \mathrm{~h}$,

f) construction and operation of hunting weapons and ammunition, construction, operation and use of optical instruments and other hunting equipment $-7 \mathrm{~h}$,

g) the principles of safe and effective use of hunting weapons, including the principles of firing shots and firing bullets at smooth-bore and threaded barrel weapons $-8 \mathrm{~h}$,

h) basic game diseases and methods of their recognition-2 $\mathrm{h}$.

i) hunting cynology $-4 \mathrm{~h}$,

j) rules of ethics, culture and hunting traditions, including hunting language and hunting signals, culture-forming role of hunting, hunting history -5 ,

k) rules for handling hunted game, using venison and preparing trophies -4 ,

1) rules for conducting hunting economy, including ecology, principles for shaping and renovating ecological corridors-9,

m) principles and methods of providing first aid in emergency-2,

n) compulsory training and shooting (minimum two), including shooting with smooth-bore and threaded barrel weapons (...).

o) shaping the image of a modern hunter, principles of using social media-2.

2) Selection hunting licence:
} 
Hunting in Poland is regularly the victim of media infodemic. One can cite here even the provision concerning the prohibition of intentional obstruction of hunting presented in the media as a restriction of free stay in the forest, which have aroused objections visible in public space. Some journalists (cf. [78]) have emotionally threatened that for walking in the woods or riding a bike, you could be sent to prison. In fact, however, this provision concerned activists blocking hunting and thus hindering the fight against African Swine Fever (ASF) among wild boars. It has quickly turned out that activists' protests have stopped and no stroller has been imprisoned. Furthermore, the fact that restrictions are introduced for security reasons, refer only to a small area of the hunting district and only 4-6 days a year when collective hunting is organized in a given place is not mentioned in the public discussions at all.

We do not have a satisfactory theory and definition of tradition. It seems impossible to build such a theory in an objectified way [55: 120-121]. However, it seems crucial to combine tradition with the continuation of elements of the past in the present [19: 12]. Therefore, the continuity of the practice of transferring and using hunting skills organized by PZ€ must be treated as a continuation of traditional knowledge and skills related to nature.

In order to achieve success during the hunt, the hunter is obliged to develop knowledge about biology and ecology of selected species, etc. This knowledge goes beyond the ability to distinguish species and includes, for example, knowledge of environmental and feeding selectivity of animals, their daily activities and knowledge of migration routes. It is important to know the behaviour of species, especially during the mating season (ethology). Before making a decision about firing a shot, the hunter should make a careful observation and assessment-determining the species, its gender, age, health condition, because such knowledge is the basis for deciding (selection) which individual should be shot in accordance with legal provisions

\section{Footnote 2 (continued)}
a) knowledge of the criteria for selective hunting of deer and mouflons -8 ,
b) biology, with particular emphasis on reproductive behaviour, of deer, including antler growth and development, taking into account environmental conditions, genetics-7,
c) knowledge of the principles of proper management of deer populations-7,
d) principles of practical assessment of deer age before and after shooting - 10 ,
e) the rules for assessing the validity of hunting and trophies for medals $-6 \mathrm{~h}$.
f) rules for safe and effective shooting of deer, shooting of a weapon equipped with optical sights, $-1 \mathrm{~h}$,
g) the principles and methods of providing first aid in an emergency- $1 \mathrm{~h}$.
3) Falconry hunting license:
a) legal regulations regarding the protection of birds of prey- $5 \mathrm{~h}$,
b) characteristics and recognition of native species of birds of prey $-8 \mathrm{~h}$,
c) terms and conditions of keeping birds of prey in captivity $-5 \mathrm{~h}$,
d) rules for training hunting with hunting birds $-5 \mathrm{~h}$,
e) the history and tradition of falconry and falconry ethics $-2 \mathrm{~h}$,
f) rules of conduct with hunting birds during hunting $-3 \mathrm{~h}$.
g) the principles and methods of providing first aid in an emergency- $1 \mathrm{~h}$.
4) Authorization to use hunting weapons with threaded barrels:
a) training in the use of hunting weapons with threaded barrels for persons referred to in $\S 14$ of the Regulation of the Minister of the Environment of December 28, 2009 on the right to perform hunting, covers the scope specified in paragraph 1 point 1 letter fi $g$,
b) obligatory shooting training with weapons with threaded barrels. 
and a specific seasonal hunting licence issued for a given district. Thus, this traditional knowledge has been passed down from generation to generation, because practical field observation skills cannot be learned from textbooks or in a classroom. A direct teacher-student relationship is needed.

There are reasons to believe that such knowledge is also a type of scientific knowledge (scientific observation, empirical observation). The information obtained by hunters is the basis for animal monitoring, which in turn is the basis for population management-the protection or reduction of selected species. Therefore, this issue can be analyzed from several perspectives, e.g. economic (hunting, forestry, agriculture, fisheries), environmental (protection, conservation and use of resources), cultural (hunting language, music, literature or painting inspired by hunting), social (conflict resolution-threat to human life or health). Thus, this knowledge or its effects may be used not only by selected professional groups such as foresters, farmers or scientists but also by the whole society.

There is one more aspect of hunting that is worth mentioning, that is to say generational solidarity. Hunters pass a specific system of values, principles covering attitude to nature, but also knowledge and skills from generation to generation [24]. Traditionally, the knowledge and skills have been passed from father to son. Theoretical knowledge has been propagated in textbooks for centuries and such historical examples can be the oldest Polish hunting literature, such as Mateusz Cygański's "Myślistwo Ptasze" [Hunting with Birds of Prey] from 1584 [6] and Jan Ostroróg's "Myślistwo z ogary" [Hunting with Hounds] from 1618 [53]. In turn, knowledge and practical skills have been taught and learnt during hunting.

Maciejowski [40] presented the training and requirements for candidates for hunters for the first time in an organized manner in 1841. According to this author, a boy with predisposition and interest in hunting from an early age could be a hunter. He would learn from the old hunter not only the art of hunting, but also gutting, skinning, and cutting the carcass. He would learn how to play the hunting horn and distinguish basic hunting signals. As soon as he acquired the necessary knowledge, he had the honour to be accepted as a hunter. Moreover, from a $16^{\text {th }}$ century poem by Fabian Klonowic (1545-1620) [57:187-188] we learn that a person who did not acquire the versatile hunting knowledge, including the language of hunters, was mercilessly ostracized, which in fact enables us to conclude that the acquisition of traditional knowledge passed from generation to generation was extremely important in the past.

Currently, the most important element in the hunters' training system is the annual hunting internship, during which each candidate has a designated supervisor who is an experienced hunter. It is a direct transfer of knowledge and skills on the master-student level. This is the most effective form of education. As mentioned above, only after completing the internship, the candidate for a hunter participates in a series of dozens of lectures on courses, deepening and systematizing knowledge about hunting and hunting culture, but also during classes at the shooting range covering the principles of safe handling and effective use of weapons so that animals can be killed without unnecessary suffering. The proof of the depth of knowledge that is passed down from generation to generation is the accuracy of the hunting language used to communicate among hunters. This language is characterized by 
a very small segmentation of reality and communication economics, in particular in the field of recognition of animal species on the basis of their appearance, left marks and clues, emitted smell and sounds, as well as the characteristics of their body parts.

It is worth mentioning one more element of hunting culture, that is to say the language used by hunters. The language of hunting is definitely a language for specific purposes. It status as a language for specific purposes is confirmed by the analysis of the domains in which it is used. First of all it is the language used for both occupational and academic purposes [35, 60, 62, 77]. As far as occupational purposes are concerned it is the language which is used by forest rangers, employees of the animal breeding centres, court experts, academics working in the field, et cetera. As far as the language for academic purposes is concerned it is the language of course books written by scientists specialising in natural sciences, who write about hunting as a branch of forestry and ecology. The status of sustainable hunting management or sustainable wildlife management including hunting is confirmed by the fact that there are courses at the level of higher education and secondary vocational education devoted to the topic in numerous European countries (cf. [42, 44]). It is a language for specific purposes used for occupational and academic purposes. It is also the language used by people who perform the activities carried out within the structures of the Polish Hunting Association under the Act Hunting Law of 1994 [80].

One should also remember that the languages of hunting and gathering are the oldest languages for specific purposes that evolved together with the first hunters and gatherers communities (cf. [41, 43, 44]). The existence of the language throughout the ages may be confirmed by the analysis of written sources that have survived until modern times. We find hunting vocabulary not only in prose but also in poetry. What is more, that language is undergoing constant development as a result of changing reality. Some terms become archaic whereas others enrich the lexicon [42].

The analysis of the language of hunting enables us to uncover one of its features that is to say the economy. The economy in general serves the purpose communicating in a precise, concise, fast and effective way. The efficiency of communication was especially important in the past when in order to survive it was necessary to inform about the reality precisely and succinctly (cf. [42]). In order to use the language efficiently one needs to know the meaning of specific terms and must be able to use those terms appropriately in the communicative situation in which interlocutors are. As a result the inside knowledge is necessary for the appropriate usage of the signs of the hunting language. What is typical of hunting terms is that they unambiguously convey explicitly and implicitly complex information about the reality. Among such terms we may enumerate: patry 'eyes of a hare or rabbit', stuchy 'ears of a hare or rabbit', etc.

The preservation of the language of hunting seems to be important as together with the disappearance of people who can use the language and who understand it, the level of understanding of messages including literature, poetry, course books, the knowledge about the history decreases. Linguists when discussing natural languages claim that: 
Languages are becoming extinct at twice the rate of endangered mammals and 4 times the rate of endangered birds. If this trend continues, the world of the future could be dominated by a dozen or fewer languages. Even higher rates of linguistic devastation are possible. [52].

Though the quote refers to natural languages, the analyses of the languages of hunting (which are sort of sublanguages) in Greece [20], Great Britain [41], United States of America [41], China [22] reveals that unless the language is cultivated and protected against disappearance, it suffers from regression, fast degradation, simplification, and may even lose its status of the language for specific purposes.

What is more, the analysis of translations from English into Polish of books devoted to natural sciences and environment in general inform us about the limited knowledge of general language users about the surrounding world. The content of the National Corpus of Polish [51]) also reveals such problems when in texts translated from foreign languages we find phrases rogi jelenie 'red deer horns' instead of poroże jelenia 'red deer antlers'. The experiment carried out by one of the authors of the paper [45] as well as the research results of Czołnik [11: 214-215], ${ }^{3}$ Czołnik and Roźmiarek [12] indicate that although children study environment and biology during the compulsory courses starting from primary school and ending at the secondary level, the course books disappointingly focus on the environment and biology of other countries and regions than the one in which we live. The course books devote from a minimum of 0,27 to a maximum of $18,83 \%$ to the environment of Poland including forest and their inhabitants. Out of five biggest mammals living in Poland an average Pole can successfully identify only one, that is to say the European bison which is a symbol of Poland, is frequently used as a trademark for various types of alcohol such as vodka or beer and its image is popularised in mass media and shops. The other species that is to say the elk, red deer, fallow deer and roe deer are not identified properly and the nomenclatural denoting them is frequently erroneously used [45]. What is more, the information on local environment and its problems is not reliably provided which leads to the distorted image of the local condition through a prism of global problems or local foreign country problems [11: 220].

The protection of disappearing languages is one of the most important tasks of modern linguistics. There is no denying the fact that the moment the people using such languages die out, the languages die too. If hunting is banned altogether, people will stop learning the language of hunting in Poland as there will be no need to use it and there will be no opportunity to use the language in nonhunting settings. The number of people who learnt the language will decrease day by day. The language will stop developing and will gradually become forgotten. As a consequence

\footnotetext{
3 "As far as nature textbooks for students in grades 4-6 of primary school are concerned, 3.00 to $18.83 \%$ and on average $12.10 \%$ of the coursebook is devoted to forest issues (Ortell 2015). In biology textbooks for 1 st-3rd grade students of lower secondary school, forest content occupies from $0.76 \%$ to $15.38 \%$, with the average of $6.68 \%$, and in geography textbooks, analogically, from $0.27 \%$ to $6.95 \%$ with an average of $2.96 \%$. The data shows that the most content devoted to forests may be found in nature textbooks, half less in biology textbooks, and the least in geography textbooks, because only a quarter of what can be found in nature textbooks. It should be stressed here that two-thirds of the forest related content in the studied textbooks are photos, drawings, charts and infographics.".
} 
the understanding of messages formulated in that language will decrease in society. It will become an obsolete artefact of the past.

Each natural language is a cultural code which conveys information about the knowledge, experience and practices of communities of its users. Therefore each language deserves protection as it is a reflection of the cultural identity of the community of its users. Hunting tradition and practices including sustainable wildlife management have been passed in Poland from generation to generation. The language used by hunters strengthens the bonds between individual members of the community and enhances the sense of solidarity and responsibility towards the environment and nature. The importance attached to the proper usage of the language in Poland observed for the last centuries reveals that there are strong generation bonds between hunters and the cultural sensibility and community development depend on those bonds.

Furthermore, the language enables the reconstruction of cultural codes relevant to the identity of the community of hunters for the possessors of the in-depth knowledge and continuation of deeply rooted practices. The fact that practices are deeply rooted does not mean that they do not undergo changes. The language also reveals all the changes that are introduced as a result of new discoveries, results of research of scientists and broadening knowledge in the field of sustainable wildlife management. The language which is a cultural code serves the purposes of efficient communication in a precise way which in fact enhances community identity preservation, cultural continuity of communication and the transfer of knowledge from generation to generation. It should be remembered that scholars investigating endangered languages are preoccupied with politics of their protection and access to them.

If my first concern is with the politics of access to 'endangered' languages, my second and closely related concern is with practices of writing, in the first instance because written text artifacts (and other documentary recordings) are obviously the loci of new kinds of encounters between people and the 'heritage languages' they claim as their own. In local communities, documentary materials on endangered languages of cultural heritage are not only aids to memory, but are also endowed with generative potential in their own right, because from them additional texts in the language, written as well as 'oral', can be produced. [50].

To sum up, One should remember that depriving the community of the need to use a language leads to the language degradation and consequently makes them endangered. Additionally:

endangered languages constitute an irreplaceable treasure, not only for the communities who speak them, but also for scientists and scholars.

Each endangered language embodies unique local knowledge of the cultures and natural systems in the region in which it is spoken.

These languages are among the few sources of evidence for filling in the record of the human past. 
The great variety of these languages represents a vast, largely unmapped terrain on which linguists, cognitive scientists, and philosophers can chart the full capabilities_-and limits—of the human mind. [50].

Though the quote refers to native languages, and not their fragments in the form of languages for specific purposes but taking into account the fact that the language of hunting is one of the oldest LSPs definitely makes it a treasure from linguistic and cultural perspectives.

However, the objections are raised in the public debate against the recognition of this knowledge and practices as worthy of protection as an intangible cultural heritage. The verification of the negative and positive premises for such a decision is provided in the subsequent test elements.

Element 2 the lack of conflict with the principles arising from universal human rights instruments

Subjecting the Convention on the Intangible Cultural Heritage [103] to the human rights regime is, in practice, very problematic despite the fact that such rights are anchored in the content of the Convention and its implementing directives. It is due to the fact that it automatically creates a division into a heritage that is compatible and incompatible with human rights. Consequently, depending on the type of regulations and their interpretations that are taken into account, this division always diminishes the area of intangible cultural heritage. The above-mentioned division should not, in fact, take place because it results in the censorship of cultural heritage not so much by human rights' laws as by Western European standards and interpretation of human rights, cultural standards of political correctness. Those factors in fact limit the admissibility of specific manifestations of intangible cultural heritage, and even worse, they limit even the reflection on these manifestations.

Any entry into the lists provided for in ICH may only relate to behaviours that are not in conflict with universal human rights standards arising from the instruments indicated in the preamble to the Convention. It is repeated in the discussion that it is not clear how we can use human rights to demarcate the cultural heritages that deserve protection [37: 33]. It is possible to determine that some local legislation and locally accepted cultural practices are contradictory with the Universal Declaration of Human Rights. However, in this foundation of universal human rights there are no clear bases that allow to recognize the transmission and exercise of hunting skills cultivated by PZ€ as a violation of human rights. They do not pose any threat to the life, freedom and security of another person (Article 3). Art. 27 (providing a guarantee of participation in the cultural life) of the Declaration cannot constitute the grounds for determining that hunters in Poland violate human rights. Hunting-related activities organized as part of PZŁ activities have been noticed in Polish cultural discourse of the last several hundred years. However, they do not limit the freedom to participate in them and take advantage of them. In public discourse one may encounter both speeches that build the image of hunting as bloody bestiality (the blood sport) and as an element of national cultural identity. This negative 
or even hostile message is widely present in social media, in which young activists are a very active group, the overwhelming majority of whom live in cities, far away from wild nature $[46,47]$. Hunting, on the other hand, has been a part of the national cultural identity, having been present in countless literary or artistic works for centuries, including the works of the greatest Polish poets and writers such as Adam Mickiewicz or Henryk Sienkiewicz, on the canvases of famous painters such as Julian Fałat, Juliusz Kossak, Wojciech Kossak, Jerzy Kossak or Alfred WieruszKowalski and outstanding musicians such as Feliks Nowowiejski. Dynak [13, 14] presented this issues extensively.

Globally, cultural heritage has not become an important topic for human rights discussions [68: 5]. Logan's thought can be taken as an inspiration in filling in this gap. He has noted that when discussing human rights when delineating the boundaries of intangible cultural heritage worthy of protection, "the most valuable is the declaration" that no right can be exercised at the expense of another [37: 45]. This rule deeply-rooted in legal tradition in concreto takes-according to experienceone of two forms. It could lead to the precise imposition of restrictions on a specific right or to the establishment of limits on the use of the right, the violation of which constitutes some abuse of law. In the standard of equal treatment of entities fundamental to the universal human rights regime (Article 7 of the Declaration), it is not possible for a conflict of rights or interests to lead to the recognition that one of them is extinguished. In contrast, Polish law provides clear restrictions on the use of hunting knowledge and skills in the interest of other members of society. In the interest of protecting the life and health of others, the organization of hunting requires, in particular, compliance with law [80, 97, 98]. Hunters need to know how to hunt so as not to pose a threat to other people. ${ }^{4}$

\footnotetext{
4 2. The hunters hunting at night shall exercise exceptional care, and in particular they shall:

(1) know exactly the terrain in the hunting area;

(2) not shoot towards settlements and public roads;

(3) before the shot, personally recognize the target and area on the shot line through the binoculars in the cases specified in paragraph 7.1(1), as well as in the event referred to in paragraph 7.1(1a), when using optical devices defined in para. 4.1 to perform the hunting;

(4) in the event of firing the shot and not retrieving the game at night, check the result of the shot at daylight.

Paragraph 13.
}

1. Aiming to the game and firing is allowed only after the personal and detailed recognition of the game and in conditions that guarantee the effectiveness of the shot and the ability to retrieve the game as well as the safety of the surroundings.

2. The hunter may fire shots to the game at a distance not greater than:

(1) $40 \mathrm{~m}$ - in the event of a pellet or slug shot from a smooth barrel weapon;

(2) $100 \mathrm{~m}$ - in the event of a bullet shot from a rifle with rifled barrels, using iron sights;

(3) $200 \mathrm{~m}$ - in the event of a bullet shot from a rifle with rifled barrels, using optical sights.

Paragraph 17.

On a group hunting:

(1) the hunter shall not shoot along the hunters' line; the shot along the line of hunters shall be the shot whereby the bullet or external bundle of pellets pass or if extended would pass in the distance less than $10 \mathrm{~m}$ from the neighbour's stand;

(2) the hunter shall not shoot from the stands on the hunters' line towards the stands on the flanks and 
Another important issue is the role of hunters in hunting or trapping animals that are fed, aggressive or sick (e.g. suffering from rabies), which are increasingly appearing in the urban environment [90]. Rules and programs for dealing with wild animals present in cities are being developed, and hunters play a key role in them, performing these duties for free.

It can therefore be concluded that the transfer and use of hunting knowledge and skills in the practice of PZ€ is a manifestation of the intangible cultural heritage, which is not in conflict with the standards based on universal instruments of human rights. Of course, not every acceptable manifestation of intangible heritage deserves recognition as worth recommending for protection based on $\mathrm{ICH}$. Already signaled protests against hunting cause that subsequent elements of the test require careful consideration in order to find out the answer to the question whether there are positive premises justifying such a recommendation.

Element 3 the significance of hunting knowledge and skills for nature protection and conservation

The law on the protection of cultural heritage has been shaped to a large extent by the environmental protection laws. The main problem for environmental protection law is the scope of economic activity which the law considers safe for the environment and environmental balance, among others health of present and future generations. For the heritage protection law, which is, after all, an intangible heritage, the problem of exploiting heritage, its vitality and preservation for future generations, is also the most important element. There is a regulatory and even instrumental analogy between these two branches of law. In relation to hunting, there is a noticeable intersection of the "common area" of heritage protection law, environmental

\section{Footnote 4 (continued)}

from stands on the flanks towards the hunters' lines, if the distance between these stands or the terrain do not ensure safety;

(3) the hunter shall not occupy the stands in terrain ditches, excavations and depressions;

(4) after taking the stand, the hunter shall take a standing or sitting position;

(5) shooting may only take place from a standing position; this restriction shall not apply to shots taken from hunting stands;

(6) a bullet shot to the game outside the drive cover is allowed at a distance of no more than $100 \mathrm{~m}$;

(7) a bullet shot to the game into the drive cover is allowed, with extreme caution, at a distance of no more than $40 \mathrm{~m}$, and in the case of group hunts from hunting stands - at a distance of no more than $80 \mathrm{~m}$;

(8) shooting at Cervidae into the drive cover may only take place with the consent of the huntmaster, under conditions guaranteeing safety; this consent is not required during group hunts from hunting stands;

(9) the hunter shall not shoot at the game into the drive cover if the drivers are at a distance of less than $150 \mathrm{~m}$ from the hunter in the open area and at a distance of less than $100 \mathrm{~m}$ from the hunter in the forest area;

(10) the hunter may shoot birds in flight towards drivers or towards other hunters if the shot goes up at an angle of not less than $60^{\circ}$, and there are no branches or other barriers on the line of fire;

(11) the hunter may shoot between drives with the consent of the huntmaster only to the wounded or sick animal.

Paragraph 18.

When hunting from a boat, only one hunter at a time may shoot at the game, firing in a direction other than persons on the boat. 
protection law and nature protection law. At the same time, there is sometimes a far greater gap between these "traditional allies" depicted in journalistic narrative than it really is. Increasingly stringent regulations for environmental protection can sometimes limit or even threaten the protection of cultural heritage, including intangible heritage. However, the effect is much weaker than it may be deducted from the extensive journalistic polemics. Here, the proportionality test should play an important role, and in practice it is important to study a casu ad casum at the stage of ex-ante regulation impact assessment. There should be a balance in this respect at the regulatory level. However, the primacy of always one part, i.e. environmental protection law, in relation to the intangible cultural heritage is often solely intuitive and it should not be a rule.

Nature protection and ecological values are seen by the majority as something good. An important legal instrument for achieving these values is the title "Environment" in the Treaty establishing the European Community [102]. It contains provisions specifying the objectives of policies in this respect (Article 174 of the consolidated version of the Treaty) and competence norms allowing for their implementation (Article 175 of the consolidated version of the Treaty). On this basis, a significant acquis of secondary European law has been created, which in a number of issues sets the minimum standard for nature protection in the member countries (e.g. Council Directive 92/43/EEC of 21 May 1992 on the conservation of natural habitats and of wild fauna and flora as amended [83] and Directive 2009/147/EC of the European Parliament and of the Council of 30 November 2009 on the conservation of wild birds [89]). The Treaty indicates as one of the Community's objectives "preserving, protecting and improving the quality of the environment" (Article 174 (1)). It is functionally combined with the protection of natural heritage. A clear reference to the importance of heritage in European legal instruments is contained in the European Landscape Convention of 2000 [91]. In its preamble, the landscape is clearly linked to the European natural and cultural heritage. This preamble has extensively referred to international heritage protection instruments in force at the time of the signing of the Convention. In the European dimension, the ICH, which was adopted in 2003 and in fact entered into force in 2006, should therefore be treated as an enrichment of earlier regional laws combining nature protection and conservation with broadly understood heritage protection. As a part of the currently discussed element of the legal test, this means that the transfer and use of hunting skills within PZE may be considered a form of heritage that deserves protection if it significantly supports the implementation of objectives in the field of nature protection that result from the instruments of international law and Polish legislation. Article 1 of the Polish Hunting Law [80] states that hunting is an element of nature protection and conservation. Pursuant to Polish law, the use of hunting skills may affect the natural environment only in such a way that: they serve the purpose of the preservation of the diversity of the game populations and result in maintaining the appropriate population sizes of individual game species while maintaining the balance of the natural environment. Failure to conduct such activities would lead to very adverse effects on the preservation of the natural heritage, or more broadly the natural environment. In this context, an important task is the reduction of invasive 
species such as the Asian raccoon dog (Nyctereutes procyonoides), racoon (Procyon lotor) and American mink (Neovison vison), which have a negative impact on the domestic fauna, especially waterfowl, whose numbers are dynamically decreasing. Hunters in Poland shoot about 150,000 predators (mainly foxes) a year [23], which is important for the protection of the population of the black grouse (Lyrurus tetrix) and the capercaillie (Tetrao urogallus), which are becoming rarer and are endangered with extinction.

Another important dimension of the input of hunting knowledge and skills which is transmitted and cultivated by PZ€ is the unique knowledge that allows to understand phenomena occurring in nature and to interact with the natural environment. Hunting itself, whose task is to reduce the number of certain species, is a must (cf. the Dutch [18] and Geneva [92] ${ }^{5}$ examples of apparent alternatives to hunting). The desire to succeed during hunting forces hunters to possess specific skills. The hunter must have the skill of camouflage, masking himself to "merge" with the environment to be imperceptible. In addition, he should be able to move quietly, creep depending on the direction of the wind, so that the animals do not hear and sense him. An important skill is recognizing the signs of the presence of animals and their traces and tracks, recognizing smells and sounds. A specific skill is to imitate the voices of animals (luring) e.g. a stag deer in a rut (depending on the age and herd hierarchy), a roe deer male during rut, the sounds of predator victims (mouse squeaking, hare brooding). Hunters also develop skills in training dogs, falcons and safe usage of weapons. To acquire such skills you need many years of experience gained while working in the field, which is why ordinary nature lovers do not have such skills as a rule. Nevertheless, not only they and their loved ones take advantage of their skills, e.g. venison consumers also enjoy healthy meals thanks to them.

Again, one can ask a question whether hunting is needed and whether it can be eliminated. The analysis of the situation and solutions applied in other countries can be helpful here. In several European countries, social opposition has led to an apparent ban on hunting. In essence, however, the need to kill animals has remained, because the damage they cause is extremely severe for humans. In place of traditional hunting, the killing of animals by sanitary, veterinary or professional rangers is being introduced. Killing wild geese in gas chambers can be considered an attempt for implementing such an alternative. ${ }^{6}$

\footnotetext{
5 In 1974 in the Geneva Canton a complete ban on hunting was introduced. But the environment does not follow human laws. The animal populations quickly got out of control and started inflicting damage. Right now the animals' populations are regulated by professional forest wardens who cull them. The culling takes place at night on cultivated lands where animals inflict the majority of damage [74].

6 "Population numbers of wild animals sometimes need to be controlled. Welfare considerations are increasingly recognised in the area of 'pest control' (eg [36]). Numbers of wild geese are increasing in The Netherlands, due to overabundance of food, reduced hunting and improved breeding areas [76]. Grazing of wild geese may contribute to species diversity in nature areas, but it may also cause overgrazing and financial damage for property owners. Between 2000 and 2004, on average, $€ 185,000$ were paid for damage caused by geese that visit during the summer, especially Greylag geese (Anser anser) [76]. In 2010 , the total damage caused by these geese had increased to $€ 1.8 \mathrm{~m}$ (€6.2 $\mathrm{m}$ for the total of all geese; [17]). The issue of how to deal with overabundant wild geese is hotly debated in The Netherlands. The Flora and Fauna Act allows for the capturing and killing of wild animals. A commonly used method in The Netherlands is to gather wild geese during moulting and to trap and kill the animals with carbon dioxide (CO2)." [14].
} 
Despite the criticism of hunting formulated in the public debate, an alternative to PZŁ practices or a model of reliable transmission and practice of such skills have not been developed in Poland so far. At the same time, experience shows that hunters' skills have repeatedly proven to be fundamental to taking action to protect nature. This can be illustrated by recalling several examples of species that were endangered with extinction. ${ }^{7}$

The wars usually impose an enormous strain on wildlife not only destroying habitats and environment but also making people fight for survival and nutritious food. Animals are a valuable source of protein which alleviates hunger. The animals that became extinct or almost extinct in the course of the first and second world wars in the territory of contemporary Poland included the European bison, beaver, elk and European mink.

In the interwar period Jan Sztolcman, a zoologist and hunter, graduate of zoology at the Imperial University of Warsaw got interested in the fate of the largest land mammals inhabiting Europe that is to say the European bison. Other scholars shared his opinion that the species deserves better fate. It should be remembered that in the Białowieża Forest alone German troops killed about 600 animals during the First World War [58]. The last two bison specimens were killed in 1921 in Poland and in 1927 in Caucasus. Only a few animals remained in zoological gardens.

The concept of restoring the European bison using animals kept in zoos originated in several countries and was publicly presented for the first time by a Polish zoologist J. Sztolcman at the 1st International Congress of Nature Protection in Paris, 1923 [72, 73]. The Congress supported the appeal and expressed a desire to establish an international society for the protection of the European bison. Actes du Congres International pour la Protection de la Nature, Paris 1923, (p. 93) states that “...an international society should be created, in the shortest possible time, among those countries on whose territory European bison still exist", as well as, “... other nations should offer them financial assistance and that the League of the American Bison make its experience available to the new assembly". By August 25-26, 1923, the International Society for Protection of European Bison [Internationale Geselschaft zur Erhaltung des Wisents] was founded in Frankfurt am Main. It included 16 countries. Dr K. Primel, the managing director of the zoological garden in Frankfurt was elected as President. The statute of the Society included the maintenance of the European bison by planned breeding and distribution, followed by introductions to large forest complexes. [59].

The project has turned out to be successful. One century later we may clearly state that there are several groups of animals living wild and the project of introducing the bison into habitats all over Europe is in progress. In Great Britain the reintroduction of the species is in progress.

\footnotetext{
7 The traditions of species protection date back to Middle Ages. One of the examples is the Statute (in Polish: Statut warecki) enacted by King Władysław Jagiełło in 1423, which introduced penalties for poaching.
} 
The second species that is worth mentioning here is the beaver (Castor). Beavers, similarly as European bison, became extinct in Poland during the Second World War. Throughout the centuries they were protected by law. Unfortunately as they were believed to be panacea for numerous diseases, they suffered from poaching. Even sever penalties did not deter poachers. Additionally, the fact that they live in lodges that are easy to track, makes them vulnerable. The dams they construct are also a nuisance for farmers and may lead to agricultural damage. All those factors, combined with starving troops in the territory of Poland resulted in the eradication of the species. The zoological books published in 50ties and 60ties described the species as extinct (cf. [65: 83]). The program of an active protection of beavers was implemented successfully in 1976 by professor Wirgiliusz Żurowski working in the Polish Academy of Sciences in Popielno. The program encompassed the introduction of 4-6 pairs of beavers along the Vistula and Odra rivers. From 1975 till 2007 over 1400 beavers were bred and introduced into those territories (cf. [32: 402]).

In 2015, UN member states adopted the 2030 Agenda for Sustainable Development [105], and within its framework it has been recognized at the international level that cultural heritage and its diversity are a driving force of inclusive development. Thus, the use of living heritage, i.e. mainly intangible cultural heritage for the purposes of sustainable development, can help communities build societies with greater openness and tolerance. At the same time, 17 sustainable development goals have been developed, including the following: "Goal 15: Protect, restore and promote sustainable use of terrestrial ecosystems, sustainably manage forests, combat desertification, and halt and reverse land degradation and halt biodiversity loss" [105]. The role of hunting in this respect is important not only in the field of sustainable exploitation of ecosystems, but above all in preventing the loss of biodiversity. As already mentioned, the protection of endangered species by hunters is manifested, inter alia, by increasing endangered species populations or reintroduction of species that no longer occur in their natural environment. Such an example could be the capercaillie, whose population in Poland has dropped dynamically, reaching levels below 500 individuals. Hunters have begun breeding this species and increasing the population by releasing the bred individuals into the forest environment. For example, in the years 2004-2014, a total of 530 young capercaillies (from 14 to 90 per year) were resettled in the Silesian Beskids [30]. We should mention here one more important achievement of Polish hunters which is strictly connected with the reintroduction of endangered species. It is an innovative method called "born to be free" which was developed in Poland in nineties of twentieth century by Krzywiński and applied for the first time in 2004 [33, 34]. The method encompasses a motherassisted rearing of young and release technique that increases the survival rate of the young. „Born to be free” project involves the preparation of animals to life in natural habitat. As Krzywiński et al. [33: 241] states it takes into account the need of enriching and collecting the genetic material of wild animals which can be be used for re-creation of populations even after they become extinct. The method is successfully applied to breeding and releasing to natural environment the following species of animals: lynx, capercaillie, black grouse [34, 48, 49].

Additionally, due to the use of DDT to combat harmful insects after World War II, the peregrine falcon (Falco peregrinus) has become extinct in Poland. Thanks to 
breeding and a reintroduction program, in the years 2010-2015 almost 550 falcons were released, as a result of which this species is present again in Polish forests [67].

One cannot forget that the person who pointed out and propagated the need to change the role of hunting in $20^{\text {th }}$ century was professor Szczerbiński from Poznan University of Natural Sciences. In fact he is a father of ecology as a sciences and sustainable hunting management as a tool for preserving biodiversity in a given territory [26].

The 2003 Convention may play an important role in the implementation of the 2030 Agenda for Sustainable Development [105] as a tool for implementing the potential of intangible cultural heritage in terms of environmental sustainability, social and economic development. During the sixth session, the General Assembly of the States Parties to the Convention in 2016 adopted the Sixth Chapter of Operational Directives [96]—Knowledge and practices regarding nature and the universe. According to them, States Parties to the Convention are to endeavor to ensure the recognition, respect, sharing and deepening of knowledge and practices regarding nature and the universe recognized by communities, groups and, in some cases, individuals within the intangible cultural heritage that contribute to sustainable environmental development, recognizing their ability to evolve, exploiting the potential role in protecting biodiversity and the sustainable management of natural resources. The specification of the provisions of the Convention contained in the Operational Directives [96] goes far beyond the initial idea of the conceptual scope of "knowledge and practice regarding nature and the universe", as it encourages States Parties directly to:

(a) recognize communities, groups and individuals as the bearers of knowledge about nature and the universe and as essential actors in sustaining the environment;

(b) foster scientific studies and research methodologies, including those conducted by the communities and groups themselves, aimed at understanding systems of biodiversity conservation, natural resource management and sustainable resource use, that are recognized by communities, groups and, in some cases, individuals as part of their intangible cultural heritage, and demonstrating their effectiveness while promoting international cooperation for the identification and sharing of good practices;

(c) adopt appropriate legal, technical, administrative and financial measures to:

c.i. promote access to and transmission of traditional knowledge concerning nature and the universe while respecting customary practices governing access to specific aspects of it;

c.ii. conserve and protect those natural spaces whose existence is necessary for expressing the intangible cultural heritage. [96]

To sum up, the transfer and use of hunting knowledge and skills in the practice of PZ€ should be considered a manifestation of intangible cultural heritage, which is of great importance for nature conservation in Poland as there is no doubt that hunters (members of PZ€) who form a community are also bearers of knowledge about nature and the universe necessary for environmental protection and conservation, and thus the State-Party to the Convention should be open to supporting these 
activities in the field of hunting as an intangible cultural heritage, which are indicated in the above-mentioned chapter of Operational Directives [96].

Element 4 the significance of hunting knowledge and skills for economic balance and internal security

The basis of this test is a proposal to change the paradigm. We believe that a deeper, more complete approach to the intangible heritage manifested in hunting skills requires going beyond combining relationships with nature with specific hunting practices, associated with rituals. By relying on specific practices such as the skills of Korean female divers, you can stress their importance for "eco-friendly methods and community involvement in management of fishing practices." This heritage was inscribed on the representative list in 2016 [87]. However, a significantly broader view of the manifestation of intangible heritage as a whole conglomerate of knowledge and hunting skills performed as part of PZŁ opens up new opportunities and possibilities. Of course, one should respectfully refer to the natural criticism of behaviour in pluralistic society that results in the killing of a game animal in course of hunting. In a pluralistic society, we also recognize as legitimate the criticism of yoga, recognized as a manifestation of intangible heritage (entry from 2016) [86], which is questioned as an occult practice completely contradictory to Christian tradition (e.g. [75]; [79]). There were serious doubts whether to recognize traditional songs of Korean female divers which are anti-Japanese in content as a protected form of intangible heritage [38: 17]. A broad perspective of the analysis of hunting knowledge and skills leads to a broad diversification of their meaning. It goes far beyond the community that cultivates hunting traditions. It concerns two values important for social balance: economic balance and security. Polish law combines hunting with the rationality of agriculture, forestry and fishing (Article 1 of the Hunting Law). It regulates in detail the rules of the hunting economy (Articles 8-16) and conducting business activities in the field of hunting (Articles 18-22b). This legal framework has specific economic content, significant for public revenues, risk allocation of damage caused by wild animals and the labor market.

Sustainable hunting is a branch of economy which brings to the budget some income but its most important aspect is reducing costs incurred by the state. The Polish hunting model presupposes that wildlife belongs to the state. The hunting clubs lease hunting grounds where they may exercise the right to hunt for selected species of game. They pay the lease fee for the territory in which they are allowed to hunt. In 2019 hunters in one out of 49 districts (the Szczecin district) paid the rent in the amount of PLN 1,163,619.

At the same time they take over the burden of assessing damage to crops inflicted by wild game species and paying out compensation to farmers. The hunters are also obliged to reduce the population of deer species in accordance with instructions and plans of the State Forests to keep the number of animals at the level consistent with the feeding capacity of a given territory. The number of red deer in Poland is growing dynamically, and the extent of damage caused by them is increasing. The State Forests managing forests covering an area of over 7 million ha spend about PLN 180 million per year on deer fencing (over Euro 42 million). Despite this, as a result of 
foraging the surface of about 90 thousand ha is damaged [99]. Another problem concerns damage caused by animals in agricultural crops. Considering the costs of night duty carried out by hunters guarding sowing against damage caused by wild boars, costs of estimating damages resting on hunters' shoulders, costs of compensation paid to farmers, the estimated expenses related to agricultural damage are estimated at about PLN 0.5 billion per year (over EUR 110 million) [3].

Polish hunters also bear costs connected with combating diseases spreading among animals such as the above-mentioned African Swine Fever. The cost of combating the disease in one out of 49 hunting districts (the Szczecin district) is amounted to be PLN 57,173. The Szczecin district is located in the so-called white zone where ASF has not been detected yet and the majority of the costs were borne in the last two months of the financial year (1st April 2019 till 31 March 2020) on bio-security packages. In the Gorzów Wielkopolski District (mostly white zone and two gminas in a yellow zone) the costs mounted to PLN 90,189, whereas in the Poznań District (mostly yellow zones and a few red ones) they amounted to PLN 382,250. Finally, in the Zielona Góra District (with mostly red zones) the costs amounted to PLN 1,001,608. The costs of ASF combating are going to grow not only because more and more red and yellow zones are delineated by veterinarian services, but also because of the doubled prices of anti-virus liquids such as Virkon necessary for bio-security procedures. Those costs do not burden the state budget but are borne by hunters.

Wild animals can cause not only material damage but also can constitute threats to humans. There are two main types of threats worth mentioning here: the risk of road accidents resulting from animal intrusion on the road and the risk of being attacked by a wild animal. Of course, one cannot eliminate them completely. However, one can limit them.

The research carried out by Czerniak et al. [7, 8] indicates that the number of road collisions and accidents with the participation of animals increases year on year. The hunters by reducing populations of animals (the numbers of which are increasing rapidly) contribute to the reduction of such events and the death toll, injuries and property damage. In 2017, 32,760 road incidents involving wild animals were recorded, resulting in 10 lives lost and 229 seriously injured. In 2017, 32,760 road incidents involving wild animals were recorded, resulting in 10 lives lost and 229 seriously injured (PAP 2018). In 2018, with fewer road accidents in general (almost 1000 fewer than in 2017), the number of collisions with animals decreased by only 13 accidents [31].

At the same time scientists design crossings for safe animal passage both above and under roads. The insight knowledge of the behaviour of animals is necessary to choose the right place for such crossing. After their construction, the monitoring of crossings is necessary to identify which species use them [7, 9, 10, 21]. It should be stressed here that in Poland the research is frequently carried out by scientists who are also hunters.

More and more frequently, the increasing populations of animals enter into a conflict with human beings. They appear in cities, visit parks, playgrounds and gardens. In such instances there is a need to eliminate the threat for safety of people posed by animals. On June 26, 2018, in Bieszczady, in the town of 
Strzebowiska, a wolf attacked two children (an 8-year-old girl and a 10-year-old boy) who were playing outside. The same wolf had previously attacked a woman in the neighboring Wetlina village,. Due to the threat the animal posed to humans, it was shot by hunters [46] with a special permit.

One more aspect affecting human and animal safety may be mentioned here. For instance the Gorzów Wielkopolski Hunting District co-operates with universities located in their territory of operation and delivers research material which is used to detect for instance the parasites in carcasses that may be dangerous for human health and well-being.

This element of the test-similarly to element number three-allows to recognize that the intangible heritage manifested in the transmission and exercise of hunting skills under PZŁ activities significantly affects the social environment. The positive effects of the impact extend to important values for the common good, such as supporting economic balance and security in public space. Such linking of hunting skills with the common good may arouse criticism. A positive assessment of a specific, human-being inherent manifestation of intangible heritage is always subject to the risk of conflict occurrence. In a pluralistic society, various developed and established behaviours can compete. The competition between the postulate to protect a specific manifestation of intangible heritage and a legitimate demand for changes in specific practices or behaviours is also possible [68: 3, 38: 17]. Therefore, the criticism cannot be the obstacle to recognizing a particular type of hunting knowledge and skills as a worthy manifestation of material heritage. The content of this criticism, however, should be closely linked to the assessment of the importance of this manifestation of intangible heritage for the broadly understood integration of society in which this form of intangible heritage occurs. The holistic analyses of human and society relations to nature require that one considers whether there is consistency between the significance of hunting knowledge and skills performed under PZŁ for economic balance and building cultural and ethical relations with nature. This is the last element of the test.

Element 5 the hunting knowledge and skills versus the idea of nature-related cultural identity

The first entry on a representative list of intangible heritage manifested in knowledge and practices of nature and the universe concerns the paramedical skills of the Kallawaya ethnic group from Bolivia (2008) [88]. The justification of the entry has emphasized that the unique skills transferred within this community are at risk due to policies pursued by major pharmaceutical companies. This is a good illustration of the idea that understanding the inclusive nature of intangible heritage is crucial for them. It is the inclusiveness understood as building cohesion by declaring recognition for a particular community, to promote this recognition as a counterweight to the tendency to standardize, to impose uniformity. The anti-universalistic, anti-Eurocentric goal of ICH has been clearly emphasized in the course of work on it (e.g. [1]). A clear rejection of the paradigm of Western cultural dominance is a part of overcoming the injustices of colonial expansion. An important element of 
the ICH understanding of this process was the 2001 UNESCO Declaration on Cultural Diversity [104]. It is called the founding act of the organization's new ethics [37: 36]. The specificity of the mentioned entry shows that it is probably easiest to combine the protection of diversity with the protection of practice, which is statistically marginal and is clearly threatened by the process of economic globalization. This is not the case of hunting skills and practices in PZÆ. However, the Polish example shows that the protection of cultural diversity has a broader dimension than that which inspired the creators of ICH. Processes taking place within the so-called western culture may also pose threats to cultural diversity. However, the question of whether PZ€ hunting is a manifestation deserving protection as intangible heritage should not be reduced to setting politically correct limits of their criticism under the slogans of ecology. The fundamental idea of the inclusiveness of intangible heritage should be understood as building the respect for the pluralism of the behaviour of people or communities. The concern for perpetuating and cultivating hunting rituals belongs to the activities of PZŁ defined by law. It is conducted and consists, for example, in teaching customs, traditions, ethics and hunting language [100].

The pluralism of traditions requires a different understanding of their inclusiveness as a criterion for evaluation and possible legal protection. The paradigm of the generic approach which we have adopted to the transmission, acquisition and exercise of hunting knowledge and skills in PZŁ as a manifestation of intangible heritage requires a broader understanding of its inclusiveness. The European Landscape Convention [91] is inspiring here. Its preamble emphasizes that natural and cultural heritage is to contribute "to human well-being and consolidation of the European identity." Therefore, the measure of the desired inclusiveness of hunting as a manifestation of intangible heritage in the form of knowledge and practices regarding nature should be to support the close cultural identity of society. The consolidation of a realistic understanding of sensitivity to and respect for nature in cultural messages and in everyday behaviours seems to be crucial for the desired shape of such an identity. Hunting is widely present in Polish culture, as mentioned above (literature, painting, music). In addition, this presence can be manifested not only in several hundred Masses of Saint Hubert organized every year (Fig. 2), but also in Old Polish cuisine based on venison, which is often treated as a manifestation of the national culinary heritage. You can read this message today in a variety of modes. One can imagine attempts to censor it, e.g. in school compulsory reading lists. Some choices will always be made. A rational barrier to such selection may be accenting in the cultural message such hunting images that are based on realistic respect for nature. Referring to the detailed and updated rules of hunting ethics promoted by PZ€ one can make a distinction between a realistic description of hunting based on respect for nature and scenes that are outside this border. An example of the former may be the respect for hunted animals which, according to the rules of hunting ethics, should not be treated as a "nameless meat loaf". This is evident during the bag presentation, when the hunters give the hunted game the honour, always in a standing position, with their hats off, listening to specific hunting signals commemorating a given species. For the hunter, both (i) the living, real and virgin nature and the laws governing it are important, as well as (ii) the benefits that can be derived from it, e.g. venison. 
We live in an era where consumers pay more and more attention to the so-called "healthy food", which is free of chemical additives and has been produced and preserved according to traditional recipes. In this context, game, and therefore meat obtained from wild animals, is considered a special source of food, because in addition to taste, it also has health-promoting properties. Such an opinion results from a justified presumption that animals living in natural conditions are free from antibiotics, growth hormones and steroids accelerating the growth of muscle mass and, as a consequence, venison has a different chemical composition than poultry, beef or pork, which is confirmed by scientific studies [27, 29].

The availability of venison is the basis for developing hunting cuisine, which is one of the pillars of Old Polish cuisine. This specific heritage of culinary culture recorded in delicious dishes, food raw materials, ingredients, kitchen techniques, equipment and tools is so unique and one of its kind that it deserves to be remembered and cultivated at every opportunity [25].

However, these benefits can be obtained only according to specific legal and ethical principles [71]. The laws of nature will not change by applying a filter of political correctness to their literary or film images. However, the bond between the Polish hunting tradition and heritage manifested in hunting knowledge and skills may support an attitude of sensitivity to nature and its proper understanding. The earlier mentioned effective actions aimed at the restitution of European bison, beavers, elk or peregrine falcons may serve as examples here. This bond with nature passed down from father to son allows us to better show the intergenerational dimension of respect for nature.

Thus, the last of the elements of the test shows that PZ€'s hunting knowledge and skills have the potential to support such drawing on Polish national culture that combines realism and ethics in relations to nature.

\section{Discussion}

There is no broad, compact regulation in the Polish law for the protection of intangible cultural heritage. Nevertheless, these issues are present in many legal acts constituting the heritage protection system. The Act on Museums of 1996 [81] is particularly important for the protection of intangible cultural heritage. In that Act the protection of intangible heritage is explicitly included in the museum mission:

A museum is a non-profit organizational unit whose purpose is to collect and permanently protect natural and cultural heritage of humanity in the tangible and intangible form, informing about the values and content of collections, disseminating the basic values of Polish and world history, science and culture, shaping cognitive and aesthetic sensitivity, and enabling the use of the collections. [81].

The interpenetration of the interrelated existence of tangible and intangible heritage indicated in the introduction is obvious. This correlation can be seen very clearly, also on the example of hunting - where the survival of intangible heritage depends on the proper preservation of material heritage objects. And vice versa, this intangible heritage provides the right context for material heritage objects. In Polish practice of 


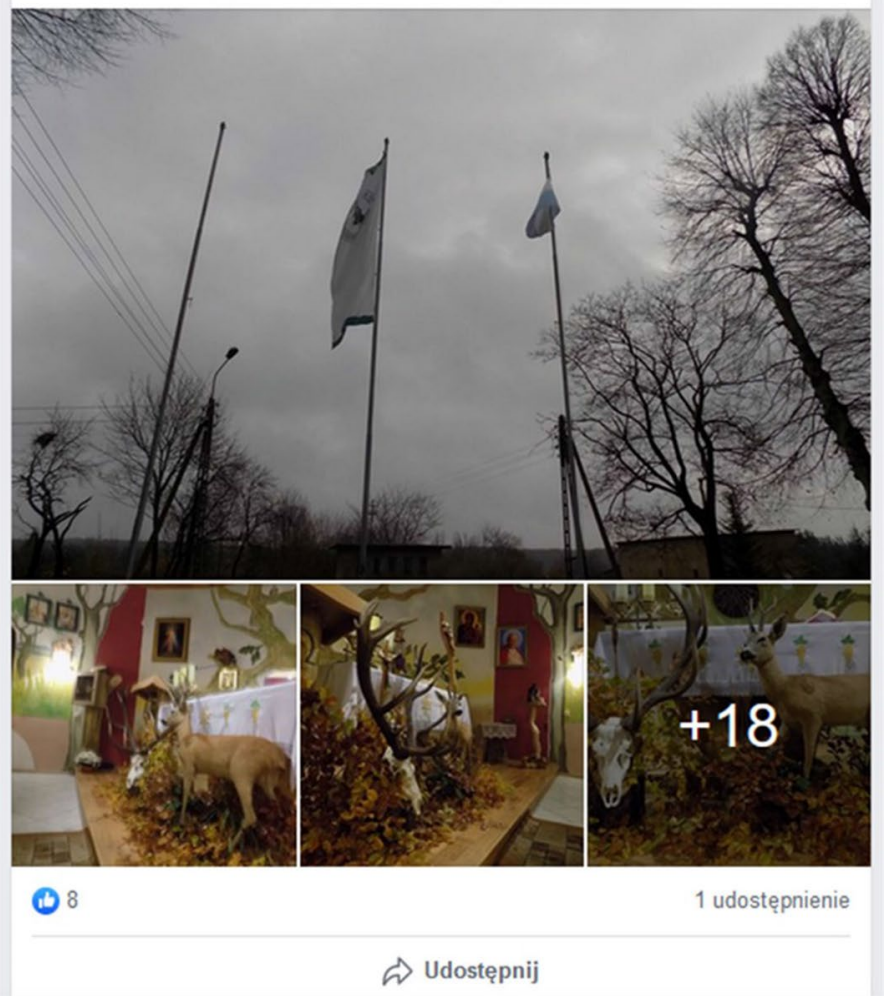

Fig. 2 Information about the Holy Mass of Saint Hubert propagated on the official website of the Konotop village [94]

applying the Convention, however, there is a contradiction in this element-on the one hand, there are hunting museums in Poland, such as the Museum of Hunting and Riding, which since 2018 has been a branch of the Royal Łazienki Museum in Warsaw or the Nature and Hunting Museum in Uzarzewo, being part of the National Museum of Agriculture and Agri-Food Industry in Szreniawa-gathering material elements of cultural heritage related to hunting. On the other hand, there is the far-reaching caution of political decision-makers in Poland in treating hunting as an intangible cultural heritage deserving to be entered in the national inventory. An important element in this respect is the fact that regulations are not yet worked out in many States Parties to the Convention, not only through developing the practice, which is always spread in time, but also resolving or indirectly addressing socially sensitive issues. In general, the developing laws and practices in the area of intangible heritage protection have in fact revealed a number of problems not only for countries that are not culturally homogeneous, but 
practically all those who must address many issues through the national protection of the heritage. And although the Convention explicitly indicates that at the national level the issue is not about the arbitrariness of the creation of such heritage registers by the authorities, but only about its registration, it is already visible at this stage that the problems multiply when the case concerns ambiguous issues. The very mechanism of entering specific manifestations of intangible heritage into the national register attracts the attention of the media and various communities, including other than the depositaries of such heritage, as a consequence, this may change the attitude and exert pressure on ministerial decision-makers keeping such records. In 2011 in the Czech Republic, "Hunting as planned sustainable management of animals and their environment as a natural part of rural life" [69: 145] was entered into the "List of intangible assets of traditional folk culture of the Czech Republic" of the Czech National Register as a result of the application filed by the Czech-Moravian hunting community. Each State Party to the Convention is required to submit reports on the activities of the implementation of the provisions of the Convention. The Czech entry has not caused any controversy at the General Assembly of the States Parties to the Convention.

Thus, it is not so that hunting cannot be a manifestation of intangible cultural heritage. It is important because it is understood as the specifics of the transience, elusiveness of intangible cultural heritage, which often preserving and transferring to subsequent generations is limited by human memory and transmitted practice. According to the test presented, one can go even further. The heritage cultivated by hunters should not be reduced to some open-air folk museum. It should be a living element valuable for the cultural cohesion of local communities, their connections and sensitivity to the natural environment, positively affecting public safety and health.

\section{Conclusions}

The normative way of protecting particularly intangible heritage must be supported by developing bottom-up activities. It is therefore logical that nobody will provide heritage with better protection than the engaged depositors. The emotional dimension of heritage, which is an inseparable element of the so-called living heritage is becoming more and more important from the point of view of its protection and management, but it can also be a cause of complications. Hunting as a manifestation of intangible heritage is the best example. In fact, although no one admits it explicitly, it is the emotional value that decides whether the cultural heritage that we find in the surrounding reality may become our cultural heritage or not. Today, one can see evolution in the approach to heritage itself, its goals and ways to achieve them. For a long time, the most important thing was to preserve the heritage intact and protect it, then the construction of preserving the value of heritage paved its way in science and in practice. At present, one can speak of another breakthrough, as the new construction is paving its way. The continuity of heritage in a given community is a central element of that construction, and it its non-material sense is more important even than the material one, as bringing together the most important element-ever-living heritage [5: 20-28]. 
Our approach to hunting as a manifestation of intangible cultural heritage is contrary to earlier legal discussion on this subject. On the basis of the Polish experience, we believe that socially significant progress in determining the correlation between hunting and the protection of intangible cultural heritage requires determining whether hunting skills and practices in a particular region or country deserve legal protection as knowledge and practices regarding nature and the universe. We have adopted this starting point being aware that it opens the field for criticism of such a postulate, but our intention has been to go beyond purely ideological arguments or political correctness. Therefore, the focus was on building an argumentation test combining the specifics of legal reasoning with in-depth knowledge of nature protection an conservation, the economic aspect, but also identity and social communication. The answer obtained in this way is clearly positive.

The transfer and application of hunting skills - in the form practiced by the Polish Hunting Association for almost one hundred years-is a manifestation of the intangible cultural heritage that deserves legal protection (Article 2 (2) d. ICH). This theoretically developed proposal requires practical verification. Generally, however, the idea is to replace the ideological dispute and barriers of political correctness with arguments based on knowledge and science, presented as required by the developed legal culture. Within this framework, it is possible to see that the postulate of legal rights of animals as law subjects are aimed at "overcoming the mental and historical baggage of the treatment of animals as law objects in Western culture" [15: 27] is in fact a postulate of the total rejection of all manifestations of intangible cultural heritage regarding human relations with the animal world. It is contrary to the practice of using ICH both in Europe and elsewhere. In the legal tradition, changes must be intertwined with continuity. The decision on legal protection of a specific manifestation of intangible cultural heritage should take into account its practical significance. Our test indicates as directions for such practical verification: the effectiveness of the nature protection and conservation system, public safety, cultural cohesion of local communities, communication continuity of a large part of the national culture output.

Last but not least, the link in the Polish case of recognition of hunting as a manifestation of intangible cultural heritage with the activities of PZŁ opens up a socially effective field of protection for the management of this heritage. We would like the next steps in the arguments and discussions presented here to be aimed at developing an innovative hunting management model of the intangible cultural heritage manifestations in Poland, and maybe in several other countries with a similar role of hunting in society.

Acknowledgements The authors would like to thank Jacek Banaszek, the Head of the Zielona Góra Hunting District, Mikołaj Jakubowski, the Head of the Poznań Hunting District, Wojciech Pawliszak, the Head of the Gorzów Wielkopolski Hunting District, and Damian Pizoń, the Head of the Szczecin Hunting District for providing data on costs of ASF combating in Poland for the hunting year 1 April 2019/31 March 2020.

Author Contributions Abstract by AM, Introduction by WD, WS, Aim and scope of the work by WD, DJG, AM, WS, Research methods and material by WD, DJG, AM, WS, The test of legal rationality by WD, WS, Element 1 - the generic coherence of hunting knowledge and skills in Poland by WD, DJG, 
AM, WS; Element 2-the lack of conflict with the principles arising from universal human rights instruments by WD, DJG, AM, WS; Element 3-the significance of hunting knowledge and skills for nature protection and conservation by WD, DJG, AM, WS; Element 4-the significance of hunting knowledge and skills for economic balance and internal security by WD, DJG, AM, WS; Element 5-the hunting knowledge and skills versus the idea of nature-related cultural identity by WD, DJG, AM, WS; Discussion by WD, DJG, AM, WS, Conclusions by WD, DJG, AM, WS; References by WD, DJG, AM, WS; Translation and proofreading by AM.

Open Access This article is licensed under a Creative Commons Attribution 4.0 International License, which permits use, sharing, adaptation, distribution and reproduction in any medium or format, as long as you give appropriate credit to the original author(s) and the source, provide a link to the Creative Commons licence, and indicate if changes were made. The images or other third party material in this article are included in the article's Creative Commons licence, unless indicated otherwise in a credit line to the material. If material is not included in the article's Creative Commons licence and your intended use is not permitted by statutory regulation or exceeds the permitted use, you will need to obtain permission directly from the copyright holder. To view a copy of this licence, visit http://creativecommons.org/ licenses/by/4.0/.

\section{References}

1. Akagawa, Natsuko, and Laurajane Smith. 2018. The practices and politics of safeguarding. In Safeguarding intangible heritage practices and politics, ed. Natsuko Akagawa and Laurajane Smith, 1-10. Abingdon-on-Thames: Routlege.

2. Bedjaoui, Mohammed. 2004. The Convention The Convention for the Safeguarding of the Intangible Cultural Heritage: The legal framework and universally recognized principles. Museum International 56 (1-2): 150-155.

3. Biliński, Paweł. 2019. Właśnie nas podliczyli. Łowiec Polski 1: 46.

4. Blake, Janet. 2003. On Developing a New International Conventionfor Safeguarding Intangible Cultural Heritage. Art Antiquity and Law 2003 VIII (4): 381-411.

5. Jagielska-Burduk, Alicja, and Wojciech Szafrański. 2016. Legal issues in cultural heritage management. A polish perspective. Frankfurt am Main: Peter Lang.

6. Cygański, Mateusz. 1999. Myślistwo ptasze. Kraków: Druk. Jakub Siebeneycher.

7. Czerniak, Andrzej, Łukasz Tyburski, and Małgorzata Górna. 2016. Przejścia dla zwierzyny elementem korytarzy migracyjnych. In Gospodarka towiecka a różnorodność biologiczna, ed. Janusz Nowacki and Maciej Skorupski, 127-141. Poznań: Fundacja Uniwersytetu Przyrodniczego w Poznaniu.

8. Czerniak, Andrzej, and Łukasz Tyburski. 2011. Zdarzenia drogowe z udziałem zwierzyny w Polsce w latach 2001-2011. Infrastruktura i ekologia terenów wiejskich, no. 3/II/2013: 5-13.

9. Czerniak, Andrzej, Ewa Bakinowska, Dariusz Kayzer, and Małgorzata Górna. 2010. Funkcjonalność przejścia dla zwierząt nad drogą krajową nr 5 w aspekcie migracji dzików (Sus scrofa). Infrastruktura i Ekologia Terenów Wiejskich 1 (2010): 207-217.

10. Czerniak, Andrzej, Antoni Miler, Sylwester Grajewski, Bernard Okoński, and Marcin Podkówka. 2013. Funkcjonalność bramowych przejść dla nietoperzy, wybudowanych na trasie S-3. Infrastruktura i Ekologia Terenów Wiejskich, no. 3/IV/2013: 165-176.

11. Czołnik, Barbara. 2017. Czego o lesie, leśnictwie i leśnikach dowiadują się uczniowie z podręczników szkolnych? Studia i Materiaty CEPL w Rogowie, no. 19. issue 50/1/2017: 214-221.

12. Czołnik, Barbara, and Benedykt Roźmiarek. 2012. Treści leśne w podręcznikach szkolnych. Studia $i$ Materiaty CEPL w Rogowie, 32 (3): 293-296.

13. Dynak, Władysław. 1994. Poezja $i$ towy. Antologia. Wrocław: Wydawnictwo Uniwersytetu Wrocławskiego. 
14. Dynak, Władysław. 2012. Łowiectwo w kulturze polskiej. Obszary i kształty obecności. Wrocław: Wydawnictwo Uniwersytetu Wrocławskiego.

15. Elżanowski, Andrzej, and Tomasz Pietrzykowski. 2013. Zwierzęta jako nieosobowe podmioty prawa. Forum Prawnicze 15 (1): 18-27.

16. Fairchild, Ruggles Dede et al. 2009. From Tangible to Intangible Heritage. In Intangible Heritage Embodied, eds. Dede Fairchild Ruggles and Helaine Silverman, 1-14. New York: Springer.

17. Faunafonds. 2010. Jaarverslag 2010. Dordrecht: Faunafonds.

18. Gerritzen, Marien A., H.G.M. Reimert, M.B.M. Sander Lourens, et al. 2013. Killing wild geese with carbon dioxide or a mixture of carbon dioxide and argon. Animal Welfare 22 (1): 5-12. https:// doi.org/10.7120/09627286.22.1.005.

19. Glenn, H.Patrick. 2014. Legal Traditions of the World, 5th ed. Oxford: Oxford University Press.

20. Gortych, Karolina. 2013. Grecka terminologia łowiecka w świetle tekstów prawnych. Investigationes Linguisticae XXVIII: 5-15.

21. Górna, Małgorzata, and Andrzej Czerniak. 2008. Analiza migracji zwierzyny leśnej przejściami wybudowanymi nad szlakami komunikacyjnymi. Infrastruktura i Ekologia Terenów Wiejskich, 2.

22. Grzybek, Joanna. 2013. Wstęp do badań w zakresie chińskiego języka łowieckiego. Investigationes Linguisticae XXVIII: 17-36.

23. GUS 2019. Statistical Yearbook of Forestry. [Rocznik Statystyczny Głównego Urzędu Statystycznego, Warszawa] https://stat.gov.pl/obszary-tematyczne/roczniki-statystyczne/roczniki-statystyczne/ rocznik-statystyczny-rzeczypospolitej-polskiej-2019,2,19.html and https://stat.gov.pl/obszary-temat yczne/roczniki-statystyczne/roczniki-statystyczne/rocznik-statystyczny-lesnictwa-2019,13,2.html. Accessed 14 May 2020.

24. Gwiazdowicz, Dariusz J. 2020. Przedmowa, czyli historia łowiectwa kołem się toczy. In: Łowy $i$ historia ed. Dariusz J. Gwiazdowicz. Sandomierz: Wydawnictwo Diecezjalne, 9-26.

25. Gwiazdowicz, Dariusz J., and Aleksandra Matulewska. 2018. Dziedzictwo kulturowe kuchni myśliwskiej. In Kultura towiecka, ed. Dariusz J. Gwiazdowicz, Józefów: Oficyna Wydawnicza FOREST: 113-119, 316-317.

26. Gwiazdowicz, Dariusz J., and Jerzy Wiśniewski. 2017. Profesor Wiesław Szczerbiński 1900-1972. Poznań: Wydawnictwo Uniwersytetu Przyrodniczego.

27. Hoffman, Louwrens C., and Eva Wiklund. 2006. Game and venison-meat for the moderns consumer. Meat Science 74: 197-208.

28. Hofmann-Wiggenhauser, Beatrice. 2017. Namengebrauch als immaterielles Kulturerbe der UNESCO: Ein Beitrag zur subjektiven Wahrnehmung des Namenraumes und die Konzeptualisierung von Namenfeldern aus Sicht des onomastischen Laien (Deutsch). Basel: Schwabe Verlag.

29. Hutchison, Christine L., Robert C. Mulley, Eva Wiklund, Jason S. Flesch, and Kearrin Sims. 2014. Effect of pelvic suspension on the instrumental meat quality characteristics of red deer (Cervus elaphus) and fallow deer (Dama dama) venison. Meat Science 98: 104-109.

30. Kamieniarz, Robert, and Zenon Rzońca. 2015. Metody oraz skala introdukcji, reintrodukcji i wsiedlania zwierzyny w Polsce. In Łowiectwo w zrównoważonej gospodarce leśnej, ed. Wojciech Gil, 91-103. Sękocin Stary: Instytut Badawczy Leśnictwa.

31. Komenda Główna Policji. Wypadki drogowe-Raporty roczne 2009-2018. http://statystyka.polic ja.pl/st/ruch-drogowy/76562,Wypadki-drogowe-raporty-roczne.html Accessed 28 November 2019.

32. Korzeniowski, Stanisław. 2018. Łowiectwo dawniej $i$ dziś. Wybrane zagadnienia. Suwałki: Wydawnictwo Uczelniane PWSZ w Suwałkach.

33. Krzywiński, Andrzej, Armin Kobus, and Marek Keller. 2011. Wsiedlanie kuraków leśnych metodą „,born to be free”. Studia i Materiaty Centrum Edukacji Przyrodniczo-Leśnej, 13(2 [33]): 241-251.

34. Krzywiński, Andrzej, Marek Keller, and Armin Kobus. 2013. "Born to be free"-an innovatory method of restitution and protection of endangered and isolated grouse populations (Tetraonidae). Vogelwelt 134: 55-64.

35. Lerat, Pierre. 1995. Les langues spécialisées, coll. “Linguistique nouvelle”. Paris: PUF.

36. Littin, K.E. 2010. Animal welfare and pest control: Meeting both conservation and animal welfare goals. Animal Welfare 19: 171-176.

37. Logan, William. 2007. Closing Pandora's box: Human rights conundrums in cultural heritage. In Dede Fairchild Ruggles and Helaine Silverman, ed. Cultural Heritage and Human Rights, 33-50. New York: Springer.

38. Logan, William. 2009. Playing the devil's advocate: Protecting intangible cultural heritage and the infringement of human rights. Historic environment 22 (3): 14-18. 
39. Lowenthal, David. 1997. The Heritage Crusade and the Spoils of History. United Kingdom: Viking UK.

40. Maciejowski, Wacław Aleksander. 1841. Łowy w Polsce do XVII wieku. Sylwan 1: 376-397.

41. Matulewska, Aleksandra. 2013. Polska i angielska terminologia dotycząca sarny w aspekcie translatologicznym. Investigationes Linguisticae XXVIII: 49-57.

42. Matulewska, Aleksandra. 2018. Specyfika języka łowieckiego. In: Kultura łowiecka, ed. Dariusz J. Gwiazdowicz, 142-149. Warszawa: Oficyna Wydawnicza FOREST, Zarząd Główny Polskiego Związku Łowieckiego.

43. Matulewska, Aleksandra. 2019. The language of hunting in translation-what is lost, what is saved. The problem of disappearing metaphors in LSP translation. In Fachsprachen in Didaktik und Translatorik: Theorie und Praxis/LSP in Teaching and Translation: Theory and Practice. Poznań Studies in Applied Linguistics/Posener Beiträge zur Angewandten Linguistik, eds. Joanna Kic-Drgas and Marta Zawacka-Najgeburska, 173-187. Frankfurt am Main: PeterLang Publishing House.

44. Matulewska, Aleksandra. 2020. Łowiectwo i myślistwo po polsku i angielsku czyli o mglistości komunikacji językowej. In Historia $i$ łowy, ed. Dariusz Gwiazdowicz, 565-589. Warszawa: Wydawnictwo Łowiec Polski.

45. Matulewska, Aleksandra. 2020. O języku przyrodniczym i łowieckim w komunikacji międzykulturowej. Studium przypadku. In: Stanisław Goźdź-Roszkowski. Łódź: Wydawnictwo Uniwersytetu Łódzkiego. (forthcoming).

46. Matulewska, Aleksandra, and Dariusz J. Gwiazdowicz. 2020. "I would kill the Director and Teachers in the School" Cyberbullying of Hunters in Poland. International Journal for the Semiotics of Law.

47. Matulewska, Aleksandra, and Dariusz J. Gwiazdowicz. 2020. Cyberbullying in Poland: A case study of aggressive messages with emojis targeted at the community of hunters in urbanized society. Social Semiotics 30 (3): 379-395.

48. Merta, Dorota, Janusz Kobielski, Andrzej Krzywiński, and Zenon Rzońca. 2013. Preliminary results of the capercaillie (Tetrao urogallus) recovery program. In Bory Dolnoślqskie Forest, south-western Poland. Vogelwelt 134: 65-74.

49. Merta, Dorota, Janusz Kobielski, Andrzej Krzywiński, et al. 2015. A new mother-assisted rearing and release technique ("born to be free") reduces the exploratory movements and increases survival of young capercaillies. European Journal of Wildlife Research 61: 299-302. https://doi.org/10.1007/ s10344-015-0899-3.

50. Moore, Robert E. 2006. Disappearing Inc: Glimpsing the sublime in the politics of access to endangered languages. Language \& Communication 26 (3-4): 296-315.

51. National Corpus of Polish (NKJP). http://nkjp.pl/Accessed on 23 April 2020.

52. Ostler, Rosemarie. 1999. Disappearing languages. The Futurist 33 (7): 16.

53. Ostroróg, Jan. 1618. Myślistwo z ogary. Kraków: Druk. Bazyli Skalski.

54. Pomian, Krzysztof. 2010. Narodziny i przemiany dziedzictwa europejskiego. In Sploty kultury, eds. Nicole Dołowy-Rybińska, Anna Gronowska, Agnieszka Karpowicz, Igor Piotrowski, Paweł Rodak, 38. Warszawa: Wydawnictwa Uniwersytetu Warszawskiego.

55. Popper, Karl. 1969. Towards a Rational Theory of Tradition. In: Conjectures and Refutations, ed. Karl Popper, 3rd ed. London: Routledge \& Kegan Paul.

56. Prott, Lyndel V. 2007. Hunting as Intangible Heritage: Some Notes on Its Manifestations. International Journal of Cultural Property: 385-398.

57. Przybecki, Jerzy. 2008. Język łowiecki - myśliwska codzienność, In Kongres Kultury Łowieckiej, ed. Marek Krzemień. Kraków: Agencja Reklamowo-Wydawnicza “Ostoja”.

58. Pucek, Zdzisław, Irena P. Belousova, Zbigniew A. Krasiński, Małgorzata Krasińska, and Wanda Olech. 10 October 2003. European bison (Bison bonasus) Current state of the species and an action plan for its conservation. Convention on the Conservation of European Wildlife and Natural Habitats. Białowieża: Mammal Research Institute, Polish Academy of Sciences.

59. Pucek, Zdzisław (ed.). 2004. European bison: Status survey and conservation action plan. Gland: IUCN.

60. Robinson, Pauline. 1991. ESP Today: A Practitioner's Guide. Hertfordshire: Prentice Hall.

61. Románková-Kuminková, Eva. 2017. Lists of intangible cultural heritage: The beginning or the end of sustainability? In: Intangible Cultural Heritage. Safeguarding experiences in central and eastern european countries and China 10th anniversary of the entry into force of the 2003 UNESCO convention through the prism of sustainable development, ed. Hanna Schreiber, 352-370. Warszawa: National Heritage Board of Poland. 
62. Sager, Juan, David Dungworth, and Peter McDonals. 1980. English Special Languages. Wiesbaden: Oscar Brandstetter.

63. Schreiber, Hanna. 2009. Niematerialne dziedzictwo kulturowe: Idea, prawo, praktyka. In: Prawna ochrona dziedzictwa kulturowego. Wokót problematyki prawnej zabytków i dziet sztuki, ed. Wojciech Szafrański and Katarzyna Zalasińska, 115-130. Poznań: Wydawnictwo Poznańskie.

64. Schreiber, Hanna. 2017. Ten remarks on the 10th anniversary of entry into force of the 2003 UNESCO Convention for the Safeguarding of the Intangible Cultural Heritage. In Intangible Cultural Heritage. Safeguarding Experiences in Central and Eastern European Countries and China 10th Anniversary of the Entry into Force of the 2003 UNESCO Convention through the Prism of Sustainable Development ed. Hanna Schreiber, 434-471. Warszawa: National Heritage Board of Poland.

65. Serafiński, Włodzimierz. 1965. Ssaki Polski. Warszawa: Państwowe Zakłady Wydawnictw Szkolnych.

66. Sielicki, Janusz. 2018. 6.2. Wartość kulturowa sokolnictwa. In: Kultura łowiecka, ed. Dariusz J. Gwiazdowicz, 178-187. Warszawa: Oficyna Wydawnicza FOREST, Zarząd Główny Polskiego Związku Łowieckiego.

67. Sielicki, Sławomir, and Janusz Sielicki. 2016. Falconry and the restoration of the Peregrine Falcon in Poland in 1990-2015. In Falconry-Its influence on biodiversity and cultural heritage in Poland and across Europe, ed. Urszula Szymak and Przemysław Sianko, 41-47. Białystok: Muzeum Podlaskie w Białymstoku.

68. Silverman, Helaine, and Fairchild Ruggles Dede. 2007. Cultural heritage and human rights. In Dede Fairchild Ruggles and Helaine Silverman, ed. Cultural Heritage and Human Rights, 3-22. New York: Springer.

69. Šimša, Martin. 2017. The strategy of safeguarding the intangible cultural heritage in the Czech Republic. In Intangible Cultural Heritage. Safeguarding Experiences in Central and Eastern European Countries and China 10th Anniversary of the Entry into Force of the 2003 UNESCO Convention through the Prism of Sustainable Development, ed. Hanna Schreiber, 142-153. Warszawa: National Heritage Board of Poland.

70. Stelmach, Jerzy. 2003. Kodeks argumentacyjny dla prawników, 1-71. Zakamycze: Kraków.

71. Szpetkowski, Krzysztof J. 2004. Etyka łowiecka, 1-109. Łowiec Polski: Warszawa.

72. Sztolcman, Jan. 1924. Matériaux pour l'histoire naturelle et pour l'historique du Bison d'Europe (Bison bonasus Linn.). Annales Zoologici Musei Polonici Historiae Naturalis 2: 49-136.

73. Sztolcman, Jan. 1925. Le bison d'Europe. Premier Congrés International pour la Protection de la Nature. Rapports, Voeux, Réalisations, Paris, France, 87-92.

74. Tomiałojć, Ludwik, and Marian Szymkiewicz. 1992. Zagadnienia ochrony ptaków drapieżnych w Polsce i problem sokolnictwa. In: Czynna ochrona zwierzat, eds. Olaczek Romuald, Tomiałojć Ludwik, 79-105. Wydawnictwo Naukowe PWN Warszawa.

75. Ron, Tyler. 2015. Freed Indeed!: My Journey from Occultism to Christ (A Spiritual Oddysey), 1-180. Enumclaw, WA: Redemption Press.

76. van der Jeugd, Henk P., Berend Voslamber, Chris van Turnhout, Henk Sierdsema, Nicole Feige, Jeroen Nienhuis, and Kees Koffijberg. 2006 Overzomerende ganzen in Nederland: Grenzen aan de groei? [Title translation: Geese staying in The Netherlands over the summer: Limits to growth?] Nederland, Beek-Ubbergen: SOVON Vogelonderzoek Nederland, Rijksuniversiteit Groningen, Carl von Ossietzky Universität Oldenburg.

77. Weber, Harmut. 1982. Language for Specific Purposes, Text Typology, and Text Analysis: Aspects of a Pragmatic-Functional Approach. In Proceedings of the 3rd European Symposium on LSP, Pragmatics and LSP eds. Jørgen Hoedt, Lita Lundquist, Heribert Picht, Jacquies Qvistgaard, 219-234. Copenhagen.

78. Wesołowska, Ewa. 2020. Las nie dla nas! Angora 4: 12-13.

79. Zwoliński, Andrzej. 2019. Joga. Zagrożenie dla chrześcijan, 1-338. Warszawa: Wydawnictwo Monument. 


\section{Websites}

80. Act of October 13, 1995 Hunting Law [Ustawa z dnia 13 października 1995 r.-Prawo łowieckie] http://isap.sejm.gov.pl/isap.nsf/download.xsp/WDU19951470713/U/D19950713Lj.pdf. Accessed on 10 March 2020.

81. Act on Museums of 21 November 1996. [Ustawa o muzeach z dnia 21 listopada $1996 \mathrm{r}$.] http://isap. sejm.gov.pl/isap.nsf/download.xsp/WDU19970050024/U/D19970024Lj.pdf. Accessed on 10 March 2020.

82. Co robią myśliwi w lesie? https://czarnaowca.org/blog/robia-mysliwi-lesie/Accessed on 1 March 2020.

83. Council Directive 92/43/EEC of 21 May 1992 on the conservation of natural habitats and of wild fauna and flora as amended https://eur-lex.europa.eu/legal-content/EN/TXT/PDF/?uri=CELEX :31992L0043\&from=EN: Accessed 10 June 2020.

84. Decision of the Intergovernmental Committee UNESCO: 14.COM $12 \mathrm{https} / / /$ ich.unesco.org/en/ decisions/14.COM/12. Accessed 10 June 2020.

85. Decision of the Intergovernmental Committee: 11.COM 10.B.15: https://ich.unesco.org/en/decis ions/11.COM/10.B.15: Accessed 10 June 2020.

86. Decision of the Intergovernmental Committee: 11.COM 10.B.17; https://ich.unesco.org/en/decis ions/11.COM/10.B.17; Accessed 10 June 2020.

87. Decision of the Intergovernmental Committee: 11.COM 10.B.24; https://ich.unesco.org/en/decis ions/11.COM/10.B.24; Accessed 10 June 2020.

88. Decision of the Intergovernmental Committee: 3.COM 1; https://ich.unesco.org/en/decisions/3. COM/1; Accessed 10. June 2020.

89. Directive 2009/147/EC of the European Parliament and of the Council of 30 November 2009 on the conservation of wild birds https://eur-lex.europa.eu/legal-content/EN/TXT/PDF/?uri=CELEX :32009L0147\&from=EN Accessed 10 June 2020.

90. Dzik ,ukradł dzieciom pierogi i je zjadł”. Nietypowa interwencja policji https://www.rmf24.pl/fakty /polska/news-dzik-ukradl-dzieciom-pierogi-i-je-zjadl-nietypowa-interwencj,nId,4537499 Accessed on 15 June 2020.

91. European Landscape Convention of 2000 https://www.coe.int/en/web/landscape/the-european-lands cape-convention. Accessed 10 June 2020.

92. Hunt-free Geneva combats wild boar population https://www.swissinfo.ch/eng/hunt-free-genev a-combats-wild-boar-population/2441024 Accessed on 10 March 2020.

93. Hunting Act 2004 (c. 37): https://www.bailii.org/cgi-bin/format.cgi?doc=/uk/legis/num_act/2004/ ukpga_20040037_en_1.html\&query=(hunting)+AND+(act) Accessed 10 June 2020.

94. Informacja o mszy św. Huberta propagowana na oficjalnej stronie sołectwa Konotop. https://pl-pl. facebook.com/KonotopZDR/posts/784862121656438/Accessed 10 June 2020.

95. Instruction how to demolish a hunting stand https://pl-pl.facebook.com/pages/category/Community/ Poznaniacy-Przeciwko-My\%C5\%9Bliwym-904637379583425/Accessed on 12 June 2020.

96. Operational Directives for the implementation of the Convention for the Safeguarding of the Intangible Heritage of 2014 https://ich.unesco.org/en/directives Accessed on 10 March 2020.

97. Regulation of the Minister of the Environment of March 16, 2005 on determining hunting periods for game animals [ROZPORZĄDZENIE MINISTRA ŚRODOWISKA z dnia 16 marca 2005 r. w sprawie określenia okresów polowań na zwierzęta łowne] https://www.infor.pl/akt-prawny/ DZU.2005.048.0000459,metryka,rozporzadzenie-ministra-srodowiska-w-sprawie-okreslenia-okres ow-polowan-na-zwierzeta-lowne.html Accessed on 10 March 2020.

98. Regulation of the Minister of the Environment of March 22, 2005 on detailed conditions for hunting and marking carcasses [Rozporządzenie Ministra Środowiska z dnia 10 września 2019 r. zmieniające rozporządzenie w sprawie szczegółowych warunków wykonywania polowania i znakowania tusz] http://isap.sejm.gov.pl/isap.nsf/DocDetails.xsp?id=WDU20190001782 Accessed on 10 March 2020.

99. Report on the state of forests 2017. https://www.lasy.gov.pl/pl/informacje/publikacje/informacje -statystyczne-i-raporty/raport-o-stanie-lasow/raport-za-2017-2.pdf/view Accessed 10 June 2020.

100. Resolution No. 266/2020 of the Supreme Hunting Council of December 2019 regarding: Introduction of training and examination instructions in the Polish Hunting Association [Uchwała nr 266/2020 Naczelnej Rady Łowieckiej z dnia grudnia 2019 roku w sprawie: Wprowadzenia 
instrukcji szkolenia i egzaminowania w Polskim Związku Łowieckim] (internal website of the PZŁ) Accessed on 10 March 2020.

101. Statut PZŁ https://www.pzlow.pl/images/Statut_PZL_z_zalacznikami_1-3.pdf Accessed on 15 April 2020.

102. Treaty establishing the European Community https://eur-lex.europa.eu/legal-content/EN/ TXT/?uri=CELEX:12002E/TXT Accessed on 16 March 2020.

103. UNESCO Convention for the Safeguarding of the Intangible Cultural Heritage (ICH) http://porta 1.unesco.org/en/ev.php-URL_ID=17716\&URL_DO=DO_TOPIC\&URL_SECTION=201.html Accessed on 10 June 2020.

104. UNESCO Declaration on Cultural Diversity http://www.unesco.org/new/fileadmin/MULTIMEDIA/ HQ/CLT/pdf/5_Cultural_Diversity_EN.pdf Accessed on 18 January 2020.

105. United Nations 2030 Agenda for Sustainable Development https://www.un.org/sustainabledeve lopment/development-agenda/Accessed on 18 January 2020.

106. Universal Declaration of Human Rights of 1948 https://www.un.org/en/universal-declaration-human -rights/, Accessed 10 June 2020.

Publisher's Note Springer Nature remains neutral with regard to jurisdictional claims in published maps and institutional affiliations.

\section{Affiliations}

\section{Wojciech Dajczak ${ }^{1,2}$ (D) Dariusz J. Gwiazdowicz ${ }^{3,4}$. Aleksandra Matulewska, ${ }^{5,6}$. Wojciech Szafrański ${ }^{1,7}$}

Wojciech Dajczak

dajczak@amu.edu.pl

Dariusz J. Gwiazdowicz

dariusz.gwiazdowicz@up.poznan.pl

1 Faculty of Law and Administration, Adam Mickiewicz University, Poznań, Poland

2 Collegium Iuridicum, Adam Mickiewicz University, Św. Marcin 90, Room 101, 61-809 Poznań, Poland

3 Faculty of Forestry, Poznań University of Life Sciences, Poznań, Poland

4 Department of Forest Protection, Collegium Maximum, Poznań University of Life Science, Wojska Polskiego 28, 60-637 Poznań, Poland

5 Faculty of Modern Languages and Literatures, Adam Mickiewicz University, Poznań, Poland

6 Collegium Novum, Adam Mickiewicz University, al. Niepodległości 4, Block A Room 107, 61-874 Poznań, Poland

7 Collegium Iuridicum Novum, Adam Mickiewicz University, Al. Niepodległości 53, 61-714 Poznań, Poland 